\title{
Level of circulating concentrations of progesterone during ovulatory follicle development affects timing of pregnancy loss in lactating dairy cows
}

\author{
J. P. N. Martins, D. Wang, N. Mu, G. F. Rossi, A. P. Martini, V. R. Martins, and J. R. Pursley ${ }^{1}$ \\ Department of Animal Science, Michigan State University, East Lansing 48824
}

\begin{abstract}
The objective of this experiment was to determine the effect of high versus low progesterone (P4) during the pre-dominance or dominance phase (or both) of ovulatory follicle development on follicular dynamics and fertility of lactating dairy cows. Progesterone (P4) was manipulated to reach high $(\mathrm{H})$ or low $(\mathrm{L})$ serum concentrations during the pre-dominance phase (d 0 to 4 of the wave) and dominance phase (d 5 to 7 of the wave) of a second follicular wave ovulatory follicle, creating 4 treatments: $\mathrm{H} / \mathrm{H}, \mathrm{H} / \mathrm{L}, \mathrm{L} / \mathrm{H}$, and L/L. Luteolysis was induced with $\mathrm{PGF}_{2 \alpha}$ on $\mathrm{d} 7$ of the wave and ovulation was induced with $\mathrm{GnRH} 56 \mathrm{~h}$ after $\mathrm{PGF}_{2 \alpha}$. Cows $(\mathrm{n}=558)$ received artificial insemination (AI) $16 \mathrm{~h}$ following GnRH. Pregnancy was determined at 6 intervals during gestation and at calving to quantify pregnancy loss beginning at d 23 post-AI utilizing pregnancy-specific protein B (PSPB) in novel withincow comparisons. Cows with single ovulations assigned to the $\mathrm{L} / \mathrm{L}$ treatment had greater pre-ovulatory follicle diameter compared with cows assigned to the $\mathrm{L} / \mathrm{H}$ or $\mathrm{H} / \mathrm{L}$ treatments. Cows with single ovulations had greater pre-ovulatory follicle diameter compared with cows with double ovulations. Low $\mathrm{P} 4$ in $\mathrm{H} / \mathrm{L}, \mathrm{L} / \mathrm{H}$, and $\mathrm{L} / \mathrm{L}$ increased double ovulation rate compared with $\mathrm{H} / \mathrm{H}$. Cows with double ovulations had greater pregnancies per AI (P/AI) on d 23 post-AI compared with cows with single ovulations but had greater losses if ovulations were unilateral. Cows with low P4 during the entire period of the ovulatory follicle development also had greater $\mathrm{P} / \mathrm{AI}$ on $\mathrm{d} 23$ post-AI compared with cows with high $\mathrm{P} 4$ during both phases. However, fullterm $\mathrm{P} / \mathrm{AI}$ was not different between treatments. This was a result of the greater incidence of pregnancy losses between d 35 and 56 of gestation for cows with unilateral double ovulations compared with bilateral double ovulations and single ovulatory cows. Cows with single
\end{abstract}

Received January 8, 2018

Accepted July 3, 2018.

${ }^{1}$ Corresponding author: pursleyr@msu.edu ovulation and low circulating P4 during the dominance period of follicle development had increased pregnancy losses between d 35 and 56 of gestation compared with cows with single ovulations and high P4. The PSPB measurements on d 16 and 23 post-AI were highly accurate in the prediction of pregnancy at $d 28$. The PSPB differed on d 23 and 28 between cows that had versus cows that did not have pregnancy losses between d 28 and 35 of gestation. In summary, circulating concentrations of P4 during ovulatory follicle development affected numbers of follicles ovulated and timing of subsequent pregnancy losses.

Key words: follicular wave, pre-dominance, dominance, embryonic death, unilateral double ovulation

\section{INTRODUCTION}

Lactating dairy cows have significantly lower circulating concentrations of steroid hormones [progesterone (P4) and estradiol] than nulliparous heifers (Sartori et al., 2004). This was due to increased metabolism of steroid hormones related to greater feed intake and milk production (Rabiee et al., 2001a,b; Sangsritavong et al., 2002). This decrease in concentrations of circulating steroid hormones is related to a series of physiological changes that is associated with a reduction in fertility of lactating dairy cows (Wiltbank et al., 2006). Lactating dairy cows exhibited shorter duration of estrus (Lopez et al., 2004), increased incidence of multiple ovulations (Lopez et al., 2005a), and larger ovulatory follicles and corpora lutea (CL) compared with dairy heifers (Sartori et al., 2004).

Fertility treatments were developed during the last $15 \mathrm{yr}$ to improve fertility of lactating dairy cows that received Ovsynch timed-AI programs (Pursley et al., 1995, 1997a,b, 1998; Wiltbank and Pursley, 2014). These programs manipulate follicle and CL development before the start of Ovsynch so that the first GnRH of Ovsynch causes ovulation of a first wave dominant follicle (Moreira et al., 2001; Peters and Pursley, 2002; Bello et al., 2006; Martins and Pursley, 2016). Fertility programs increase the likelihood of increased circulating $\mathrm{P} 4$ concentrations during growth of the ovulatory 
follicle due to the induction of an accessory CL induced in response to the first GnRH of Ovsynch (Bello et al., 2006; Martins et al., 2011a, 2017; Pursley and Martins, 2011; Jimenez-Krassel et al., 2012; Yousuf et al., 2016). Increased P4 during growth of the ovulatory follicle was associated with increased fertility of dairy cows (Fonseca et al., 1983). Previous studies that supplemented P4 during ovulatory follicle development including a recent meta-analysis with 16,683 lactating dairy cows indicated that cows without a CL were more fertile with supplementation of $\mathrm{P} 4$ during ovulatory follicular growth than without P4 supplementation (Stevenson et al., 2006, 2008; Bisinotto et al., 2015b). Low circulating P4 during the growth of the ovulatory follicle was also related to an increased risk of early pregnancy losses between d 29 and 60 post-AI in lactating dairy cows (Cunha et al., 2008). These observations suggest that low serum P4 during the development of the ovulatory follicle might be one of the critical factors leading to the increase in early embryonic death in lactating dairy cows. Fertilization rates were not affected when different circulating concentrations of $\mathrm{P} 4$ were tested during the development of the ovulatory follicle (Ahmad et al., 1995; Cerri et al., 2011b). But, low circulating concentrations of $\mathrm{P} 4$ and the subsequent increase in $\mathrm{LH}$ pulses (Roche and Ireland, 1981) can create persistent follicles and cause germinal vesicle breakdown (Revah and Butler, 1996), which leads to reduced fertility.

Gaining a greater understanding of how P4 affects embryonic survival in a cause/effect study is critical. Our central hypothesis is that high serum concentrations of $\mathrm{P} 4$ during the dominance period of the ovulatory follicle increases pregnancy per AI and reduces pregnancy loss throughout the gestation period. The main objective of this study is to determine the effect of different concentrations of $\mathrm{P} 4$ during different periods of ovulatory follicle development (pre-dominance, dominance, or both) on fertility parameters of lactating dairy cows.

\section{MATERIALS AND METHODS}

\section{Cows, Housing, and Materials}

This experiment was conducted on a commercial dairy farm (Nobis Dairy Farm, St. Johns, MI) with approximately 1,000 lactating dairy cows that were milked 3 times daily during late fall, winter, and spring. Average herd milk production during this period was approximately $42 \mathrm{~kg} /$ cow per d. Cows were housed in freestall barns, fed a TMR once daily, and had free access to food and water. The TMR consisted of corn and alfalfa silages and corn-soybean meal-based con- centrates formulated to meet or exceed nutrient recommendations for lactating dairy cows (NRC, 2001).

Trained laboratory personnel administered all injections in this experiment with single-dose syringes with 3.5-cm needles in semimembranosus or semitendinosus muscles of cows. All $\mathrm{PGF}_{2 \alpha}$ treatments in this experiment used $25 \mathrm{mg}$ of dinoprost tromethamine (Lutalyse, Zoetis, Kalamazoo, MI). All GnRH treatments used 100 to $200 \mu \mathrm{g}$ of gonadorelin hydrochloride (Factrel, Zoetis). Vaginal P4 controlled internal drug release devices (CIDR; $1.38 \mathrm{~g}$ of P4, Eazi-Breed CIDR Cattle Insert, Zoetis) utilized were new or used. Used CIDR were removed from lactating dairy cows after being inserted once for 3 or $4 \mathrm{~d}$, washed with soap and water, and disinfected with chlorhexidine gluconate solution $(0.03 \%)$ for $2 \mathrm{~h}$ as previously described by Zuluaga and Williams (2008). Used CIDR were used in the present experiment to maintain sub-luteal serum concentrations of P4. The Institutional Animal Care and Use Committee at Michigan State University approved all procedures.

\section{Experimental Design}

Pre-Synchronization Treatment. Weekly cohorts of lactating dairy cows $(\mathrm{n}=1,051)$ between 57 to 63 DIM (first service) or diagnosed not pregnant $39 \mathrm{~d}$ after previous AI (second or greater services) were presynchronized with the administration of $\mathrm{PGF}_{2 \alpha}$ then GnRH 2 d later (G7G; Bello and Pursley, 2007) to induce a new estrous cycle. Only cows that responded to these treatments with CL regression and ovulation were utilized in the experiment.

Ovaries were scanned and mapped on the day of pre-synchrony $\mathrm{GnRH}$ by transrectal ultrasonography as previously described (Martins et al., 2011b) using a color Doppler MyLabOne ultrasound with a 6 to 10 $\mathrm{MHz}$ multi-frequency linear array probe (Esaote, Indianapolis, IN). Height and width of the largest crosssection size of follicles with antrum average diameter $>7 \mathrm{~mm}$ and CL were measured using build-in calipers. Corpus luteum with a fluid-filled central cavity also had the large cross-section of the cavity measured. Diameter of smaller follicles $(\leq 7 \mathrm{~mm})$ were estimated based on on-screen lateral grids. Measurements of all follicles and CL were recorded in an ovarian map for each cow with date of examination. Ovaries were scanned with ultrasound again $2 \mathrm{~d}$ following the GnRH of the presynchronization to determine ovulation and CL regression. Ovulation was characterized by the disappearance of a follicle(s), followed by detection of a newly formed CL on the same ovary. Corpus luteum regression was determined by a decrease in the maximum luteal size 
and disappearance of luteal blood flow area using the color function of the ultrasound machine as described previously (Acosta et al., 2002; Ginther et al., 2007). Luteal regression was reevaluated $5 \mathrm{~d}$ later during the next ultrasound examination of the ovaries.

Only cows that started a new cycle were blocked by parity and AI service number then randomly assigned to 4 treatments initiated on $\mathrm{d} 7$ of the estrous cycle. On this day, GnRH (first GnRH of Ovsynch) was administered to induce a follicular wave (ovulatory wave). This day was considered d 0 of treatment and of the synchronized ovulatory follicular wave. Ovulation and the start of a new follicular wave was determined 2 d later. Only cows that ovulated and started a new follicular wave remained in this experiment $(\mathrm{n}=562)$.

Treatment. Serum P4 was manipulated to reach high or low concentrations during the pre-dominance phase ( 0 to 4 of the wave) and dominance phase (d 5 to 7 of the wave), creating 4 groups: high/high $(\mathbf{H} / \mathbf{H})$, high/low $(\mathbf{H} / \mathbf{L})$, low/high $(\mathbf{L} / \mathbf{H})$, and low/low $(\mathbf{L} / \mathbf{L})$. Day 4 of the ovulatory follicle wave was defined as the day of dominant follicle deviation based on previous studies (Sartori et al., 2001). A combination of $\mathrm{PGF}_{2 \alpha}$ and used CIDR was applied to create low serum P4. New CIDR ( 1 or 2 devices) in combination with a CL (original, accessory, or both) was used to produce a high serum $\mathrm{P} 4$.

Cows in the $\mathrm{H} / \mathrm{H}$ treatment received a new CIDR on treatment $\mathrm{d} 1$ that was replaced for a new one on $\mathrm{d} 4$. Cows in the $\mathrm{H} / \mathrm{L}$ treatment also received a new CIDR on treatment $\mathrm{d} 1$. This CIDR was replaced by a used CIDR on $\mathrm{d} 4$, and an injection of $\mathrm{PGF}_{2 \alpha}$ was administered. Another injection of $\mathrm{PGF}_{2 \alpha}$ was administered on $\mathrm{d} 5$. Cows in the $\mathrm{L} / \mathrm{H}$ treatment received an injection of $\mathrm{PGF}_{2 \alpha}$ on treatment $\mathrm{d} 0$, and a used CIDR was inserted on $\mathrm{d} 2$. This CIDR was replaced for 2 new CIDR on $\mathrm{d}$ 4. One was removed on $\mathrm{d} 7$ and the other on $\mathrm{d} 8$. Cows in the $\mathrm{L} / \mathrm{L}$ treatment received an injection of $\mathrm{PGF}_{2 \alpha}$ on $\mathrm{d} 0$ and a used CIDR on d 2, which was replaced for another used CIDR on $\mathrm{d} 4$ followed by a $\mathrm{PGF}_{2 \alpha}$. A third $\mathrm{PGF}_{2 \alpha}$ was administered on $\mathrm{d} 5$.

All cows of the experiment received $\mathrm{PGF}_{2 \alpha}$ on $\mathrm{d} 7$ to induce luteolysis. On d 8, all CIDR were removed and a second $\mathrm{PGF}_{2 \alpha}$ injection was administered to ensure luteal regression. Approximately $32 \mathrm{~h}$ later, the last injection of GnRH was administered to synchronize ovulation of the ovulatory follicle. Ovulation was determined $2 \mathrm{~d}$ following this injection as previously described, and only animals that ovulated were included in the analysis. This is sufficient time to determine ovulation because cows ovulate approximately $28 \mathrm{~h}$ following the GnRH-induced LH surge (Pursley et al., 1995) due to specific time of upregulation of collagenases and down- regulation of matrix metalloproteinases (Bakke et al., 2002, 2004; Dow et al., 2002a,b). Thus, all cows (n = 562 ) in the study had similar ovulatory follicle age at time of GnRH induced-LH surge on d 9 and by ovulation between $\mathrm{d} 10$ and 11. Corpus luteum regression after final $\mathrm{PGF}_{2 \alpha}$ was determined by a decrease of the maximum luteal size and disappearance of luteal blood flow area using the color function of the ultrasound machine on treatment d 9 and 11 as determined to the first $\mathrm{PGF}_{2 \alpha}$ of pre-treatment. Only cows with disappearance of luteal blood flow on d 9 of treatment remained in the study. The final number of cows for each treatment was $\mathrm{H} / \mathrm{H}, \mathrm{n}=134 ; \mathrm{H} / \mathrm{L}, \mathrm{n}=137 ; \mathrm{L} / \mathrm{H}, \mathrm{n}=152$; and $\mathrm{L} / \mathrm{L}$, $\mathrm{n}=139$. Supplemental Figure S1 (https://doi.org/10 .3168/jds.2018-14410) has a schematic illustration of treatments.

\section{Blood Collection and Hormone Assays}

Blood samples for measurement of $\mathrm{P} 4$ were collected from the coccygeal vein or artery of a subset of cows on treatment d $0,1,2,4,5,7$, and $9(\mathrm{n}=308)$ using Vacutainer tubes without anticoagulant (BD Vacutainer, Franklin Lakes, NJ) to validate treatments. Blood samples were collected from most cows on the experiment $(\mathrm{n}=544)$ on $\mathrm{d} 7,14,16,20,23$, and 28 after AI to measure serum concentrations of P4. Serum concentrations of pregnancy-specific protein B (PSPB) were also assessed d 16, 20,23, and 28 post-AI ( $\mathrm{n}=$ 544). Following collection, samples were refrigerated, transported to our laboratory, and maintained at $4^{\circ} \mathrm{C}$ overnight. Serum was separated within $24 \mathrm{~h}$ after collection by centrifugation at $2,000 \times g$ for 20 min at $4^{\circ} \mathrm{C}$ and stored at $-20^{\circ} \mathrm{C}$ for later $\mathrm{P} 4$ analyses for later $\mathrm{P} 4$ and PSPB determination.

Serum concentrations of P4 were measured using a commercially available solid-phase RIA kit (DIAsource ImmunoAssays, Louvain-la-Neuve, Belgium). Each assay contained all samples from the same cow arranged in sequence and with single samples. Number of treatments per assay were homogeneous and arranged randomly. Intra- and interassay coefficients of variation (CV) were 21.8 and $24.7 \%$. Serum concentrations of PSPB were measured using a commercially available quantitative sandwich ELISA assay kit (BioPRYN, BioTracking LLC, Moscow, ID), which was developed based on data from Sasser et al. (1986). Each 96-well test plate was run with 2 replicates of each standard $(0.125,0.25,0.5,1,2$, and $4 \mathrm{ng} / \mathrm{mL}$ ), control level (low and high), and samples. All samples from the same cow on $\mathrm{d} 16,20,23$, and 28 were run in the same plate. In addition, each plate contained the most uniform number of treatments per plate arranged randomly. A 
linear least square regression was used to calculate the standard curve of each plate, which was used to determine the concentration of PSPB in each sample on the plate. Value of each serum sample was calculated by the average of the 2 replicate values. The CV of each sample was also determined, and samples with CV $>10 \%$ had their PSPB measured in a new assay. Interand intraassay $\mathrm{CV}$ were determined for each control level. Intra- and interassay CV were 3.9 and $5.8 \%$.

\section{GnRH Dose Change During Trial}

Due to very low ovulation rates $(55 \%)$ to the $100 \mu \mathrm{g}$ dose of GnRH administered on d 0 of treatment (d 7 of the estrous cycle) compared with other experiments (Bello et al., 2006; Martins et al., 2011a), cows in the second half of the experiment received $200 \mu \mathrm{g}$ on that day. The low ovulation rate on treatment $\mathrm{d} 0$ was the primary reason for removal of cows from the study. Increasing this dose increased the ovulation rate from 55 to $75 \%$ to this GnRH on d 7 of the cycle. Previous evidence (Souza et al., 2009) exists that Factrel reduced ovulation rate on $\mathrm{d} 7$ of the estrous cycle compared with other GnRH products on the market. Factrel is labeled to use in a varying dose from 100 to $200 \mu \mathrm{g}$. No parameters were measured that were different between doses after d 0 of treatment. Pre-treatment GnRH and final GnRH injections maintained $100 \mu \mathrm{g}$ throughout the study. Final GnRH ovulation rates were comparable to other studies using other types of GnRH.

\section{Determination of Pregnancy and Calving Records}

Pregnancy was determined on d 23, 28, 35, 56, 117 \pm 7 , and $194 \pm 7$ post-AI. Pregnancy diagnosis on d 23 and 28 post-AI were determined by serum concentrations of PSPB. The predictor for pregnancy diagnosis on d 28 post-AI were determined by receiver operating characteristic curve analysis using the MedCalc software package (MedCalc Software, Oostende, Belgium) and pregnancy diagnosis at d 35 post-AI by ultrasonography examination as the true positive. The cut-off point for serum PSPB at $28 \mathrm{~d}$ post-AI in our study was $0.60 \mathrm{ng} / \mathrm{mL}$, which had sensitivity of $100 \%$ and specificity of $91.6 \%$. Cows with serum PSPB concentrations $>0.60 \mathrm{ng} / \mathrm{mL}$ at d 28 after AI were considered pregnant at that time.

To identify the best predictor for pregnancy diagnosis on d 23 post-AI, a receiver operating characteristic curve analysis was performed with pregnancy diagnosis at $\mathrm{d} 28$ post-AI set as the true positive. Two variables were tested: serum PSPB concentration on d 23 post$\mathrm{AI}$ and percentage increase in serum PSPB concentra- tion from basal to d 23 post-AI. Basal concentration of PSPB was calculated using the average of PSPB on d 16 and 20 post-AI. Youden index $(J)$ for both variables were calculated and the maximum value of the index was used to stipulate the optimum cut-off point for each variable. Cows with an increase in serum PSPB from basal to d 23 after AI of more than $28 \%$ were considered pregnant at that time. This percentage increase in serum concentrations of PSPB from basal to d 23 post-AI was identified as a more accurate predictor with $98.0 \%$ sensitivity and $97.0 \%$ specificity compared with serum concentrations of PSPB on d 23 post-AI, which had $92.8 \%$ sensitivity and $97.0 \%$ specificity. Only 6 cows were false negatives; however, they were also considered to be pregnant on $\mathrm{d} 23$ since they were identified as pregnant on d 28 post-AI. Another 6 cows with missing samples on d 23 post-AI but with positive pregnancy diagnosis on d 28 post-AI were also considered pregnant on d 23 post-AI.

Pregnancy diagnoses on d 35 and 56 after AI were performed by farm veterinarians blind to treatment using an Ibex Pro ultrasound (E.I. Medical Imaging, Loveland, CO). Pregnancy was confirmed by embryo presence with heartbeat. Pregnancy diagnoses on d 117 \pm 7 and $194 \pm 7$ post-AI were determined by milk concentrations of pregnancy-associated glycoproteins as a farm management routine. Milk samples were collected on test days by technicians from NorthStar Cooperative (Lansing, MI). Samples were transported to a commercial laboratory in Lansing, Michigan, on the same day (AntelBio Laboratory) and were analyzed by a commercial ELISA kit according to manufacturer instructions (IDEXX Laboratories Inc., Westbrook, ME). In a case of a negative pregnancy diagnosis by milk sample, farm veterinarians reconfirmed the test result by transrectal palpation. Pregnancy diagnosis on d 35, 56, $117 \pm 7$, and $194 \pm 7$ post-AI and calving information of each cow for the present study were retrieved from the dairy herd management computer software (PCDart, DRMS, Raleigh, NC). Calving records retrieved included date of calving, twin, sex, and stillborn.

\section{Statistical Analyses}

Binomial variables were analyzed using logistic regression with a generalized linear mixed model implemented with the GLIMMIX procedure of SAS (version 9.4, SAS Institute Inc., Cary, NC). The final model considered treatments $(\mathrm{H} / \mathrm{H}, \mathrm{H} / \mathrm{L}, \mathrm{L} / \mathrm{H}$, and $\mathrm{L} / \mathrm{L})$, parity (primiparous or multiparous), and service (first AI or second and greater AI) as fixed effects. Twoway interaction of treatment and parity or service was only considered in the model if $P<0.20$. Continuous 
variables were analyzed using a linear mixed model applying the MIXED procedure of SAS with the same fixed effects as described for the GLIMMIX procedure. Treatment and parity number interaction was only considered in the model if $P<0.20$. Differences in the percentage of cows with ovulations on left versus right ovary versus bilateral were analyzed by chi-squared test using the FREQ procedure of SAS. All analyses used a 2 -tailed test. Probability values were considered different when $P$-values were $\leq 0.05$. Serum concentrations of $\mathrm{P} 4$ and PSPB at specific times during the collection period were analyzed using the MIXED procedure of SAS with the REPEATED statement. Fixed effects included treatment, day of collection, parity, and service. Cows nested in treatment were specified in the SUBJECT option. A first-order autoregressive $[\mathrm{AR}(1)]$ covariance structure was used.

\section{Analysis of Luteal Function Following Al}

Serum P4 measurements at treatment d 9 (after $\mathrm{n}$ $=2 \mathrm{PGF}_{2 \alpha}$ treatments) in cows determined to have no luteal blood flow or no CL detectable were used as a parameter to determine a cutoff for luteolysis. This measurement was used only in determining if cows had luteolysis following AI. Cows were considered to have undergone luteolysis following AI when serum concen- trations of $\mathrm{P} 4$ decreased to $<2.21 \mathrm{ng} / \mathrm{mL}$ from a greater previously measured concentration. This threshold was calculated by the mean serum concentration of $\mathrm{P} 4$ at treatment d $9(1.17 \mathrm{ng} / \mathrm{mL})$ plus 2 times the standard deviation $(0.52 \mathrm{ng} / \mathrm{mL})$. Parity $(P=0.97)$ and service $(P=0.97)$ number were balanced between treatments.

\section{RESULTS}

\section{Effect of Treatment During Ovulatory Follicle Development on Circulating Concentrations of P4, Ovulatory Follicle Diameter, and Double Ovulation}

The $\mathrm{L} / \mathrm{H}$ and $\mathrm{L} / \mathrm{L}$ treated cows had lower serum P4 compared with cows treated with $\mathrm{H} / \mathrm{L}$ and $\mathrm{H} / \mathrm{H}$ during the pre-dominance phase of the ovulatory follicle development. The $\mathrm{H} / \mathrm{L}$ and $\mathrm{L} / \mathrm{L}$ treatments had lower serum $\mathrm{P} 4$ compared with $\mathrm{L} / \mathrm{H}$ and $\mathrm{H} / \mathrm{H}$ during the dominance phase of the ovulatory follicle development. The $\mathrm{H} / \mathrm{H}$ treatment had greater serum $\mathrm{P} 4$ compared with $\mathrm{L} / \mathrm{H}$ during the dominance phase, indicating that treatment with 2 new P4 vaginal implants (CIDR) and the presence of an accessory CL formed on $\mathrm{d} 1$ of treatment were insufficient to induce circulating $\mathrm{P} 4$ concentrations similar to $\mathrm{H} / \mathrm{H}$ (Figure 1).

Induction of low serum P4 during both stages of follicle development increased ovulatory follicle diameter

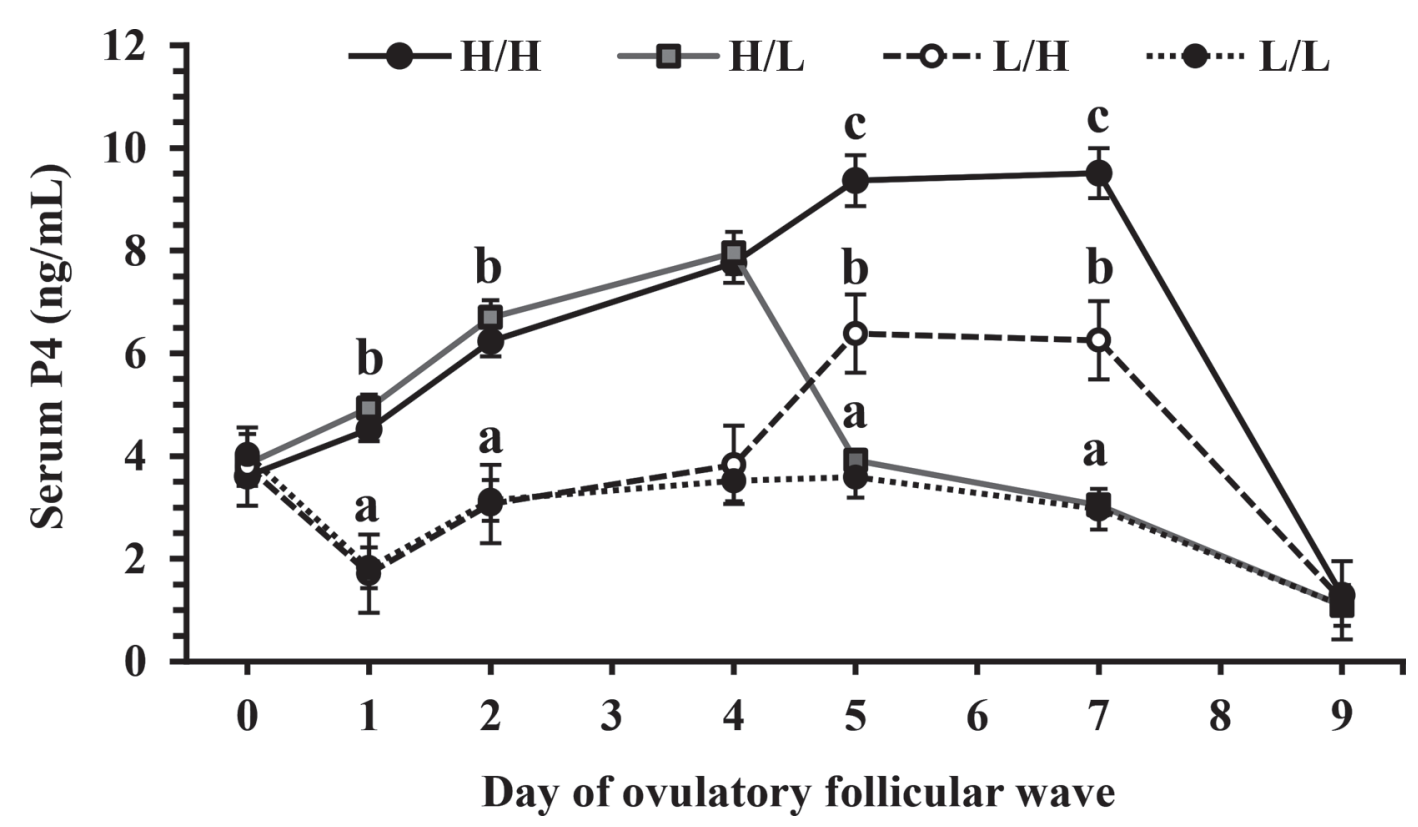

Figure 1. Serum concentrations of progesterone (P4) for lactating dairy cows $(\mathrm{n}=308)$ during the treatment period in cows treated with high or low P4 during either the pre-dominance (first $4 \mathrm{~d}$ following GnRH-induced LH surge) or dominance (d 5 to 7 of the wave, from approximate time of deviation until luteolysis) period of ovulatory follicle development $(\mathrm{H} / \mathrm{H}=$ high $\mathrm{P} 4$ during pre-dominance and dominance; $\mathrm{H} / \mathrm{L}=$ high $\mathrm{P} 4$ during pre-dominance and low $\mathrm{P} 4$ during dominance; $\mathrm{L} / \mathrm{H}=$ low $\mathrm{P} 4$ during pre-dominance and high $\mathrm{P} 4$ during dominance; $\mathrm{L} / \mathrm{L}=$ low $\mathrm{P} 4$ during pre-dominance and dominance). Data are shown as mean \pm SEM. Different letters $(\mathrm{a}-\mathrm{c})$ within a day represent differences between $\operatorname{LSM}(P<0.05)$. 


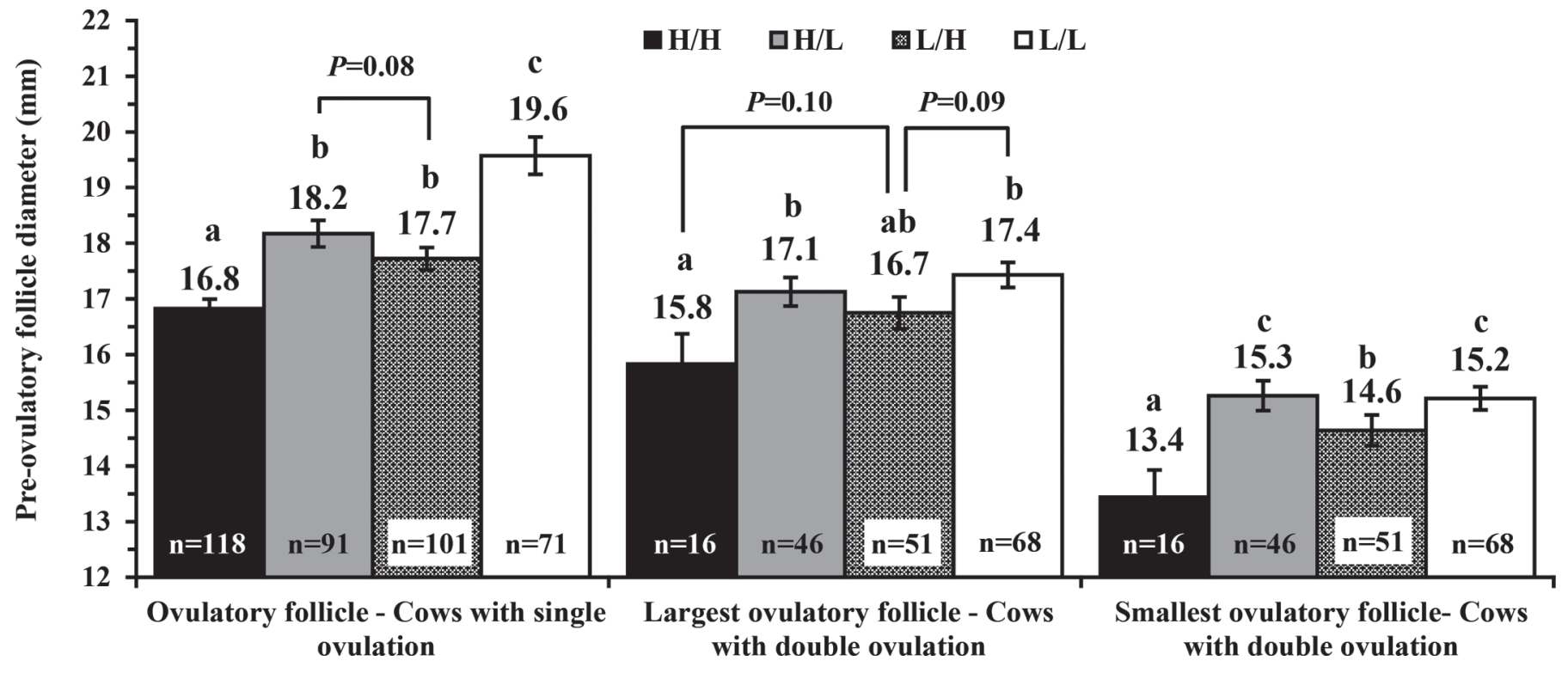

Figure 2. Effect of treatment on pre-ovulatory follicle diameter for cows with single or double ovulation in cows treated with high or low progesterone (P4) during either the pre-dominance (first $4 \mathrm{~d}$ following LH surge) or dominance (d 5 to 7 of the wave, from approximate time of deviation until luteolysis) period of ovulatory follicle development $(\mathrm{H} / \mathrm{H}=$ high $\mathrm{P} 4$ during pre-dominance and dominance; $\mathrm{H} / \mathrm{L}=\mathrm{high} \mathrm{P} 4$ during pre-dominance and low $\mathrm{P} 4$ during dominance; $\mathrm{L} / \mathrm{H}=$ low $\mathrm{P} 4$ during pre-dominance and high $\mathrm{P} 4$ during dominance; $\mathrm{L} / \mathrm{L}=$ low $\mathrm{P} 4$ during pre-dominance and dominance). Data are shown as mean \pm SEM. Different letters within pre-ovulatory follicle (single ovulation or larger follicle in double ovulation, or smaller follicle in double ovulation) represent differences (a-c; $P<0.05$ ).

(Figure 2). However, a greater effect of low serum P4 was observed during the period of dominance. The $\mathrm{L} / \mathrm{L}$ treated cows with single ovulation had greater ovulatory follicle diameter compared with $\mathrm{H} / \mathrm{H}, \mathrm{L} / \mathrm{H}$, and $\mathrm{H} / \mathrm{L}$. Cows with single ovulations had greater $(P<$ 0.001) pre-ovulatory follicle diameter compared with cows with double ovulations. Induction of low P4 during the treatment period also increased double ovulation rate (Figure $3 \mathrm{~A})$. The $\mathrm{L} / \mathrm{L}$ had greater rates of double ovulation compared with $\mathrm{H} / \mathrm{H}, \mathrm{H} / \mathrm{L}$, and $\mathrm{L} / \mathrm{H}$. The $\mathrm{H} / \mathrm{L}$ and $\mathrm{L} / \mathrm{H}$ treatments had greater double ovulation rates than $\mathrm{H} / \mathrm{H}$. Ovulatory follicle diameter was greater $(P=0.01)$ in single ovulating multiparous versus primiparous cows, but no treatment $\times$ parity interaction was present $(P=0.89)$.

Double ovulation occurrence during pre-treatment was an indicator of double ovulation rate following treatment, implying that other factors played a role in the development of co-dominance besides differences in circulating P4 concentrations (Figure 3B). No interaction between treatment and double ovulation occurrence during pre-treatment was observed $(P>0.95$; Figure 4).

Parity had an effect $(P=0.01)$ on double ovulations overall and within treatment. Multiparous cows had a greater percentage of double ovulations in $\mathrm{H} / \mathrm{H}, \mathrm{H} / \mathrm{L}$, $\mathrm{L} / \mathrm{H}$, and $\mathrm{L} / \mathrm{L}$ treatments compared with primiparous cows (16 vs. 6,45 vs. 20,42 vs. 17 , and 55 vs. $38 \%$, respectively).

Treatment did not affect side of ovulation in cows with single or double ovulation (Table 1). More single ovulating cows ovulated in the right compared with the left ovary. Cows with unilateral double ovulations tended to have greater ovulatory responses in the right compared with the left ovary.

\section{Analysis of Luteal Function and Serum Concentrations of PSPB Following Treatment}

No effect was observed of treatment $(P=0.38)$ or double ovulation following treatment $(P=0.81)$ on distribution of cows detected with luteolysis across different days following AI (Figure 5). Most nonpregnant cows on d 23 post-AI had luteolysis detected on d 20 or 23 after AI. Very few (3.0\%) nonpregnant cows on d 23 post-AI underwent luteolysis $\leq$ d 16 following AI (Figure 5). Thus none of the treatments induced short luteal phases. About $11.5 \%$ of nonpregnant cows on d 23 post-AI were considered to not have luteolysis by d 28 after AI. Neither treatment $(P=0.20)$ nor double ovulation $(P=0.44)$ influenced the percentage of nonpregnant cows on d 23 post-AI without luteal regression by d 28 post AI. 

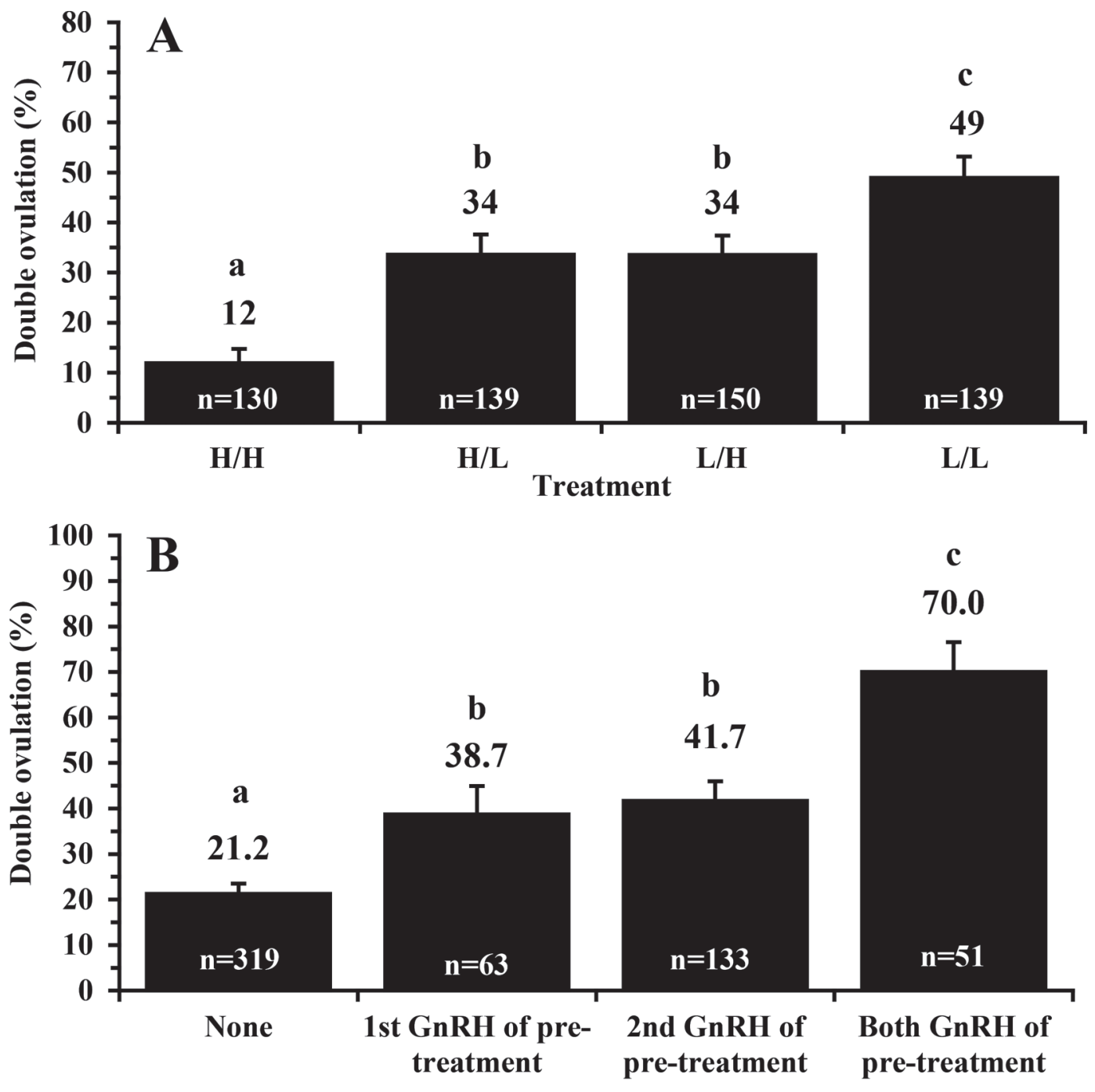

Double ovulation for GnRH injections of pre-treatment

Figure 3. Effect of treatment (A) and previous double ovulation occurrence during pre-treatment (B) on double ovulation response for the last $\mathrm{GnRH}$ of treatment in cows treated with high or low progesterone (P4) during either the pre-dominance (first $4 \mathrm{~d}$ following LH surge) or dominance ( $\mathrm{d} 5$ to 7 of the wave, from approximate time of deviation until luteolysis) period of ovulatory follicle development $(\mathrm{H} / \mathrm{H}=\mathrm{high}$ $\mathrm{P} 4$ during pre-dominance and dominance; $\mathrm{H} / \mathrm{L}=$ high $\mathrm{P} 4$ during pre-dominance and low $\mathrm{P} 4$ during dominance; $\mathrm{L} / \mathrm{H}=$ low $\mathrm{P} 4$ during predominance and high $\mathrm{P} 4$ during dominance; $\mathrm{L} / \mathrm{L}=$ low $\mathrm{P} 4$ during pre-dominance and dominance). Data are shown as mean $\pm \mathrm{SEM}$. Different letters $(\mathrm{a}-\mathrm{c})$ represent differences of LSM $(P<0.05)$.

Treatment affected serum concentrations of $\mathrm{P} 4$ following AI (Figure 6A). Cows treated with L/L had greater serum $\mathrm{P} 4$ on d 14 and 16 after AI compared with cows treated with $\mathrm{H} / \mathrm{H}$. This difference is likely due to the greater percentage of cows with double ovulation in $\mathrm{L} / \mathrm{L}$ treatment compared with $\mathrm{H} / \mathrm{H}$ and greater ovulatory follicle diameter in single ovulating cows. Cows with double ovulation had greater serum P4 on d 7, 14, and 16 after AI (Figure 6B). No treatment $\times$ parity interaction was observed in serum $\mathrm{P} 4$ during the treatment period $(P=0.20)$.
Cows diagnosed pregnant via ultrasound examination at d 35 post-AI had increased serum PSPB on d 23 and 28 post-AI compared with nonpregnant cows (Figure 7 ). The $>28 \%$ increase in serum concentrations of PSPB from d 20 to 23 post-AI was indicated as an accurate marker for pregnancy diagnosis on d 23 after AI in the present study. Cows with bilateral double ovulation had significantly increased serum PSPB d 23 and 28 post-AI compared with cows with single ovulation or cows with unilateral double ovulation (Figure $8 \mathrm{~A})$. Cows pregnant on d 28 with double ovulation also 

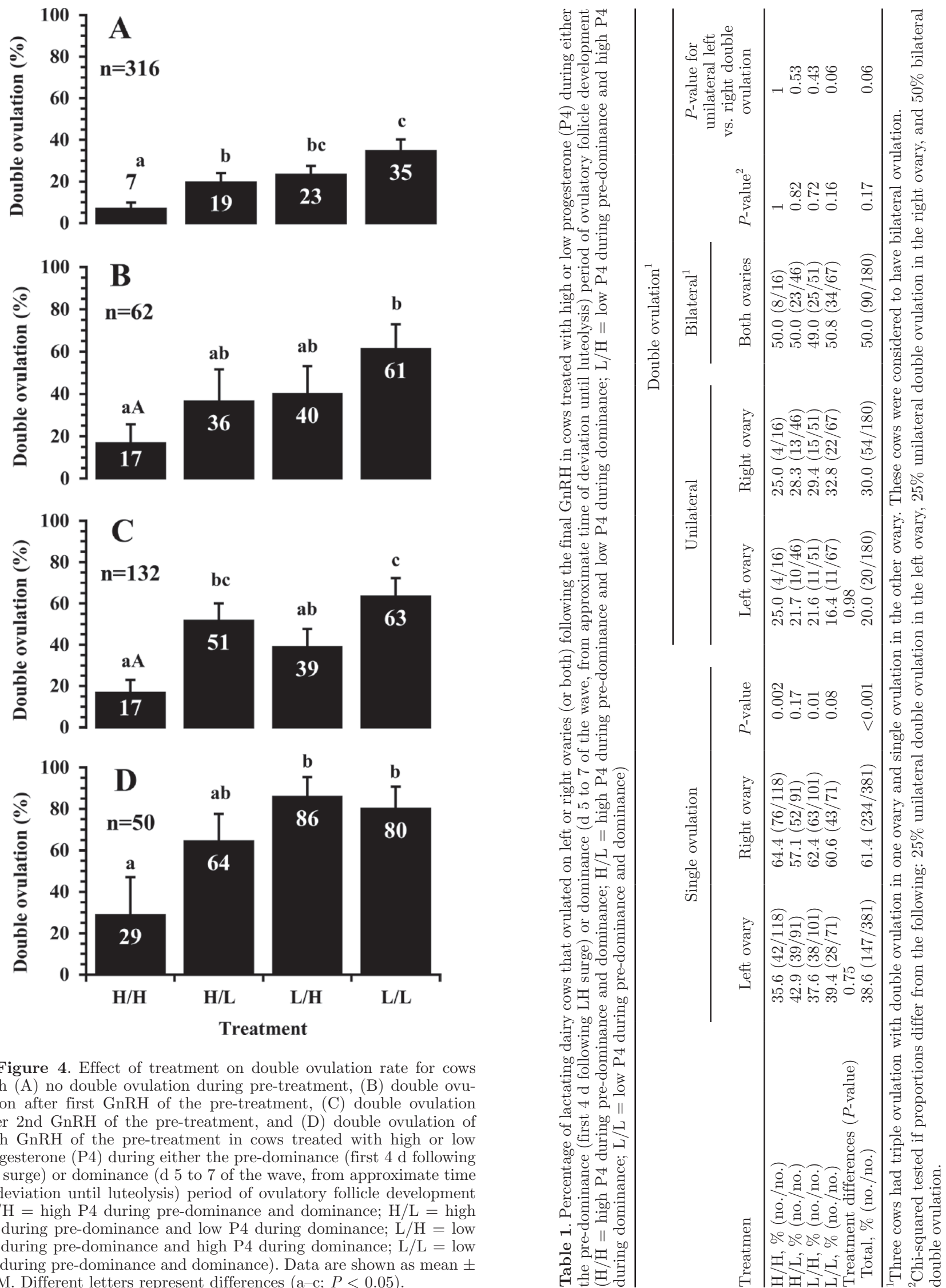

Figure 4. Effect of treatment on double ovulation rate for cows with (A) no double ovulation during pre-treatment, (B) double ovulation after first $\mathrm{GnRH}$ of the pre-treatment, (C) double ovulation after 2nd GnRH of the pre-treatment, and (D) double ovulation of both GnRH of the pre-treatment in cows treated with high or low progesterone (P4) during either the pre-dominance (first $4 \mathrm{~d}$ following LH surge) or dominance ( 5 to 7 of the wave, from approximate time of deviation until luteolysis) period of ovulatory follicle development $(\mathrm{H} / \mathrm{H}=$ high $\mathrm{P} 4$ during pre-dominance and dominance; $\mathrm{H} / \mathrm{L}=$ high $\mathrm{P} 4$ during pre-dominance and low $\mathrm{P} 4$ during dominance; $\mathrm{L} / \mathrm{H}=$ low $\mathrm{P} 4$ during pre-dominance and high $\mathrm{P} 4$ during dominance; $\mathrm{L} / \mathrm{L}=$ low $\mathrm{P} 4$ during pre-dominance and dominance). Data are shown as mean \pm SEM. Different letters represent differences $(\mathrm{a}-\mathrm{c} ; P<0.05)$. 
had greater serum P4 compared with cows with single ovulation (Figure 8B). Cows with unilateral double ovulation had similar serum circulating P4 concentrations compared with cows with bilateral double ovulations following AI. Both groups of double ovulating cows had greater circulating concentrations of $\mathrm{P} 4$ than single ovulating cows post-AI. Cows calving with twins had greater $(P<0.001)$ serum concentrations of PSPB on d $23(0.63 \pm 0.06 \mathrm{ng} / \mathrm{mL}$ vs. $0.38 \pm 0.01 \mathrm{ng} / \mathrm{mL})$ and 28 post-AI $(3.12 \pm 0.17 \mathrm{ng} / \mathrm{mL}$ vs. $2.12 \pm 0.05 \mathrm{ng} /$ $\mathrm{mL}$ ) compared with cows calving with singletons. The PSPB differed on d 23 and 28 between cows that had versus did not have pregnancy losses between d 28 and 35 of gestation (d 23, $0.41 \pm 0.01$ vs. $0.30 \pm 0.03$; d $28,2.27 \pm 0.05$ vs. $1.72 \pm 0.17)$, but not in cows that had pregnancy losses from d 35 to $56(P=0.60)$ and $>56$ to calving $(P=0.18)$. Single ovulatory cows that did not have pregnancy losses between d 28 and 35 had greater $(P=0.02)$ PSPB on d 23 and 28 versus cows that had pregnancy losses (d 23, $0.38 \pm 0.01$ vs. $0.27 \pm 0.03 ; \mathrm{d} 28,2.15 \pm 0.05$ vs. $1.72 \pm 0.20)$. The PSPB in double ovulating cows was greater on d 28 $(P=0.03)$, but not d 23 , for cows that did not have pregnancy losses between d 28 and 35 compared with cows with pregnancy losses (d 28, $2.45 \pm 0.08$ vs. 1.74 \pm 0.32 ). A parity effect was observed of concentrations of PSPB on d 23 and 28. Pregnant primiparous cows had greater $(P<0.01)$ PSPB on d 23 and 28 compared with multiparous cows (d 23, $0.47 \pm 0.02$ vs. $0.37 \pm$ $0.01 ; \mathrm{d} 28,2.37 \pm 0.07$ vs. $2.14 \pm 0.06)$. No interaction was observed between parity $\times$ double ovulation $(P>$ $0.70)$.

\section{Effect of Treatment and Double Ovulation on Fertility Parameters}

Treatment had an effect $(P=0.02)$ on $\mathrm{P} / \mathrm{AI}$ on $\mathrm{d} 23$ post-AI (Table 2 and Figure 9). Cows treated with $\mathrm{H} / \mathrm{H}$ had lower $\mathrm{P} / \mathrm{AI}$ compared with $\mathrm{L} / \mathrm{H}(P=0.05)$ and $\mathrm{L} / \mathrm{L}(P=0.001$; Table 2$)$. Cows treated with $\mathrm{L} / \mathrm{L}$ had greater pregnancy losses between d 35 and 56 post-AI compared with $\mathrm{H} / \mathrm{H}$ (Table 2). Overall percentage of pregnancy losses between d 23 post-AI to calving did not differ between treatments (Table 2). Cows treated with $\mathrm{H} / \mathrm{H}$ had a lower proportion of twin births compared with cows treated with $\mathrm{L} / \mathrm{L}$ and tended to be lower compared with cows treated with $\mathrm{H} / \mathrm{L}$ (Table 2). Cows treated with $\mathrm{L} / \mathrm{L}$ had greater $\mathrm{P} / \mathrm{AI}$ on $\mathrm{d} 23,28$, and 35 post-AI; however, on $\mathrm{d} 56$ and beyond $\mathrm{P} / \mathrm{AI}$ was similar between $\mathrm{L} / \mathrm{L}$ and $\mathrm{H} / \mathrm{H}$ due to the greater pregnancy losses in L/L between d 35 and 56 of gestation (Figure 9). There was no interaction of parity and treatment $(P>0.14)$ or service number and treatment $(>0.10)$ on $\mathrm{P} / \mathrm{AI}$ and pregnancy losses during any periods of gestation following AI.

Cows with double ovulation had greater $\mathrm{P} / \mathrm{AI}$ on $\mathrm{d}$ 23 post-AI compared with cows with single ovulation (Table 3). Cows with unilateral double ovulation had greater pregnancy losses from d 23 post-AI to calving compared with cows with single ovulation or cows with bilateral double ovulation (Table 3). Proportion of twin births was greater for cows with bilateral double ovulation compared with cows with unilateral double ovulation (Table 3). Gestation length was greater for cows with single ovulation compared with bilateral

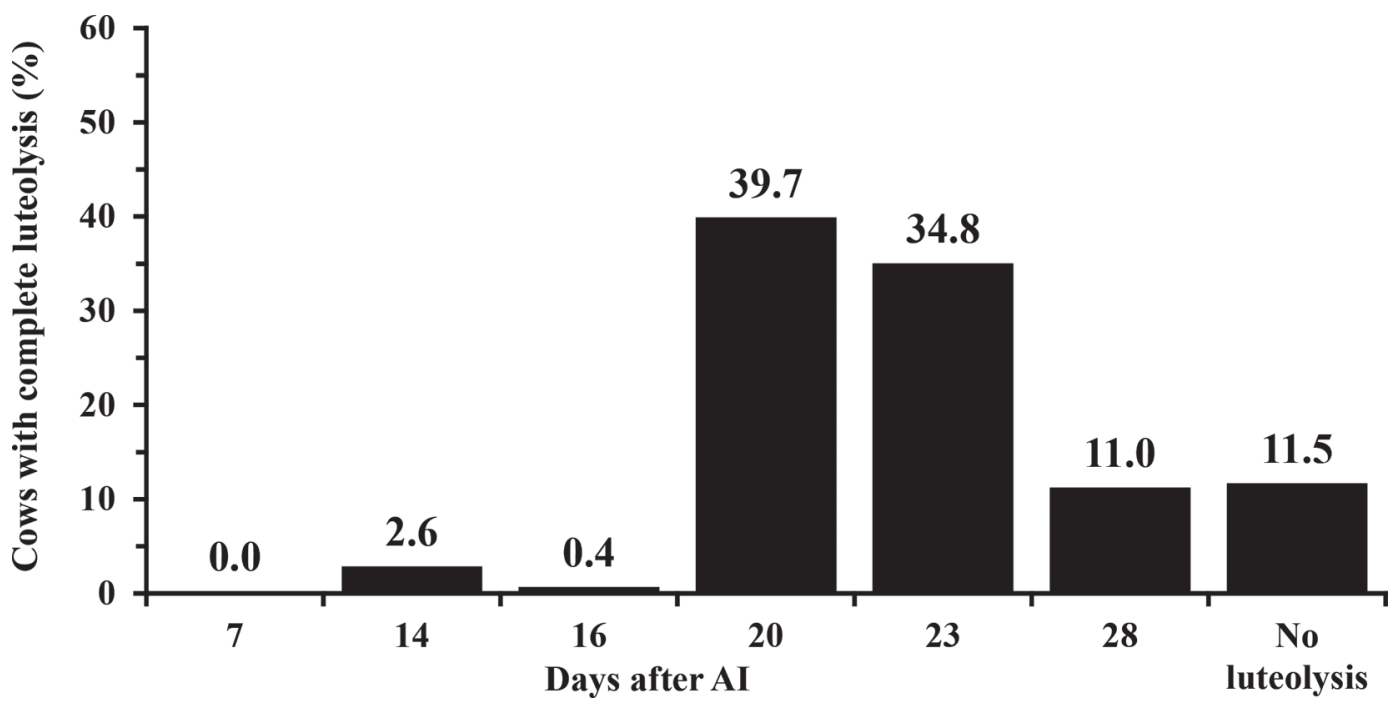

Figure 5. Percentage of cows $(\mathrm{n}=232)$ not pregnant on d 23 after AI that had luteolysis on d 7, 14, 16, 20, 23, and 28 following AI determined by decrease to basal concentrations of progesterone (P4), or no luteolysis during this period following AI. 
double ovulation (Table 3 ). Table 4 describes the effect of treatment on pregnancy losses in single and double ovulating cows. Cows in the L/L group with single ovulations had greater losses than cows with single ovulations $\mathrm{H} / \mathrm{H}, \mathrm{H} / \mathrm{L}$, and $\mathrm{L} / \mathrm{H}$.

Table 5 describes the combined effects of low or high serum $\mathrm{P} 4$ on the pre-dominance phase and dominance phase. Cows with low serum $\mathrm{P} 4$ in both pre-dominance and dominance phase $(\mathrm{H} / \mathrm{L}$ and $\mathrm{L} / \mathrm{L})$ of the follicular wave had greater $\mathrm{P} / \mathrm{AI}$ on d 23 post-AI compared with cows with high serum $\mathrm{P} 4(\mathrm{H} / \mathrm{H}$ and $\mathrm{L} / \mathrm{H})$ in both follicular wave periods. No differences were observed in $\mathrm{P} /$ AI, percentage of pregnancy loss, calving rate, gestation length, and total live calves born per total cows inseminated for cows with low versus high serum P4 during the pre-dominance phase of the follicular wave at $\mathrm{d}$ $28,35,56,117,194$, and full term. Cows treated with high $\mathrm{P} 4(\mathrm{H} / \mathrm{H}$ and $\mathrm{L} / \mathrm{H})$ during the dominance phase of the follicular wave had fewer pregnancy losses between 35 and 56 d compared with cows treated with low $\mathrm{P} 4$
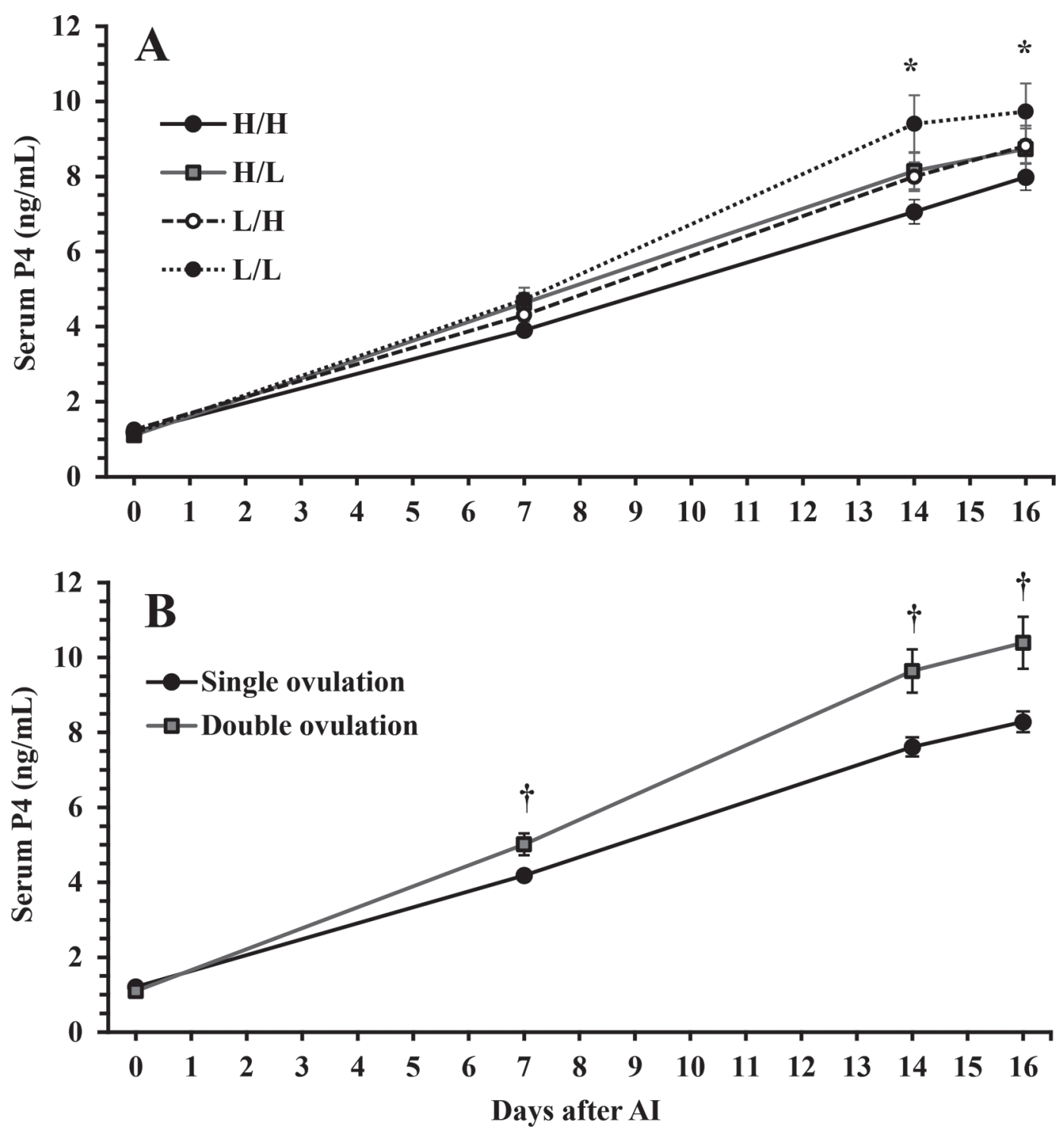

Figure 6. Mean \pm SEM serum concentrations progesterone (P4) post-AI excluding cows with early luteolysis according to (A) treatments or (B) type of ovulatory response after the last GnRH of treatment (single ovulation, unilateral double ovulation, or bilateral double ovulation) in cows $(\mathrm{n}=301)$ treated with high or low P4 during either the pre-dominance (first $4 \mathrm{~d}$ following LH surge) or dominance (d 5 to 7 of the wave, from approximate time of deviation until luteolysis) period of ovulatory follicle development $(\mathrm{H} / \mathrm{H}=\mathrm{high} \mathrm{P} 4$ during pre-dominance and dominance; $\mathrm{H} / \mathrm{L}=$ high $\mathrm{P} 4$ during pre-dominance and low $\mathrm{P} 4$ during dominance; $\mathrm{L} / \mathrm{H}=$ low $\mathrm{P} 4$ during pre-dominance and high $\mathrm{P} 4$ during dominance; $\mathrm{L} / \mathrm{L}=$ low $\mathrm{P} 4$ during pre-dominance and dominance). Pairwise differences $(P<0.05)$ within a day are represented as follows: ${ }^{*} \mathrm{~L} / \mathrm{L}$ vs. $\mathrm{H} / \mathrm{H}$ in $(\mathrm{A})$; † 


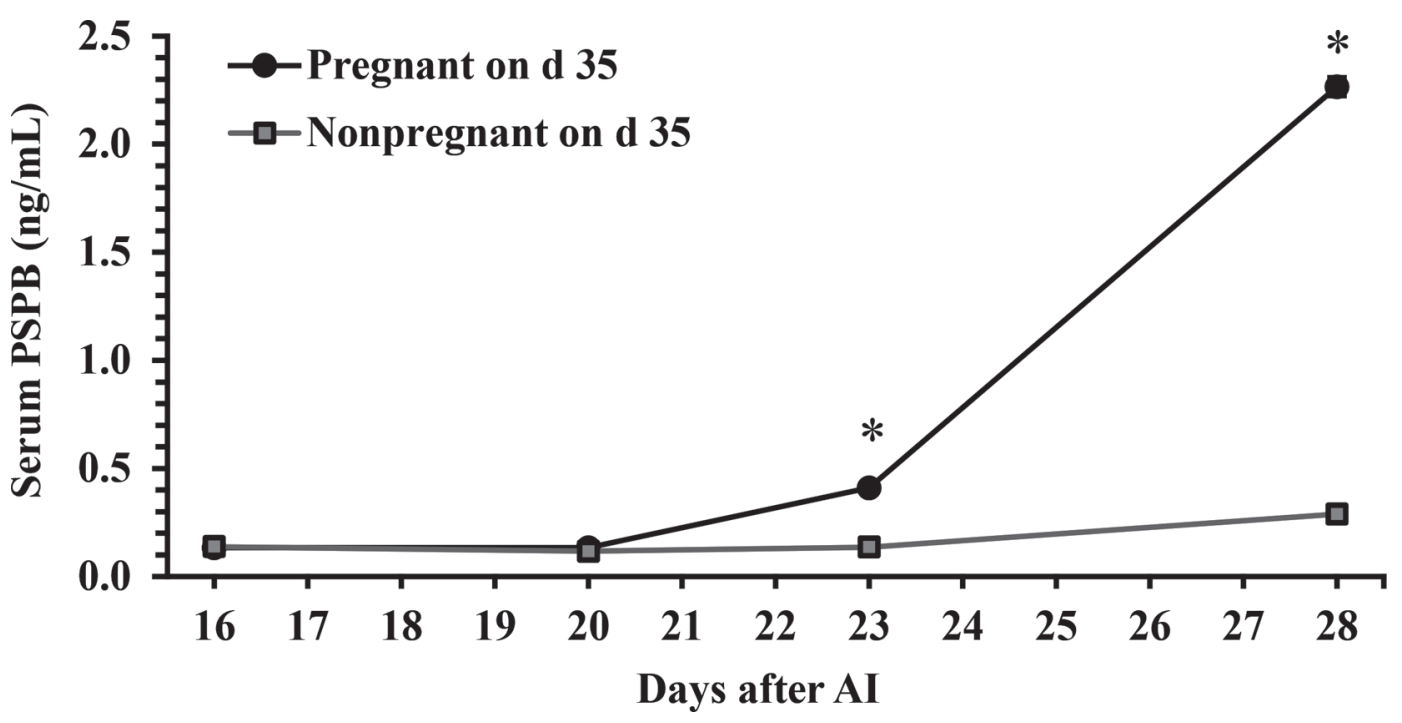

Figure 7. Mean \pm SEM serum concentrations of pregnancy-specific protein B (PSPB) for cows $(\mathrm{n}=544)$ pregnant and nonpregnant on $\mathrm{d}$ 35 post-AI. ${ }^{*}$ An asterisk represents differences of LSM within a day $(P<0.001)$.

during that period. There was an interaction between parity and treatment during the pre-dominance period for $\mathrm{P} / \mathrm{AI} 23 \mathrm{~d}$ post-AI (Table 5). Multiparous cows in $\mathrm{L} / \mathrm{H}$ and $\mathrm{L} / \mathrm{L}$ treatments combined during the predominance phase of follicle development had greater $(P$ $<0.01) \mathrm{P} / \mathrm{AI} 23 \mathrm{~d}$ post-AI compared with multiparous cows in $\mathrm{H} / \mathrm{H}$ and $\mathrm{H} / \mathrm{L}$ treatments combined during predominance (65.4 vs. $51.7 \%$ ).

Cows with single ovulations and treated with low $\mathrm{P} 4$ during the dominance phase $(\mathrm{H} / \mathrm{L}$ and $\mathrm{L} / \mathrm{L}$ combined) had similar $(P=0.68) \mathrm{P} / \mathrm{AI}$ at d 23 compared with cows with single ovulation and high $\mathrm{P} 4(\mathrm{H} / \mathrm{H}$ and $\mathrm{L} / \mathrm{H}$ combined; 52.2 vs. $50.0 \%$ ). However, single ovulating cows with low $\mathrm{P} 4$ during the dominance phase had greater $(P=0.02)$ pregnancy loss between d 28 and 56 post-AI compared with cows with high $\mathrm{P} 4$ and single ovulation (18.3 vs. $6.9 \%)$. Yet, total pregnancy loss $(P$ $=0.75 ; 23.1$ vs. $20.8 \%)$ and calving rate $(P=0.80 ; 38.5$ vs. $36.9 \%)$ were not different in cows with single ovulation with low versus high $\mathrm{P} 4$ during the dominance phase. Parity had no effect on pregnancy losses $(P>$ $0.43)$.

\section{DISCUSSION}

These data indicate that circulating $\mathrm{P} 4$ during ovulatory follicle development may regulate subsequent embryonic survival. Four key results of this study helped to explain how concentrations of $\mathrm{P} 4$ during growth of the ovulatory follicle affected pregnancy survival in this study. (1) Cows treated with low P4 had greater P/AI $23 \mathrm{~d}$ post-AI regardless of stage of follicular development compared with cows treated with high P4. (2) Low P4 treatment during follicular wave and ovulatory follicle development induced more double ovulations following the final GnRH and (3) pregnancy losses after d 35 post-AI compared with cows in the high $\mathrm{P} 4$ treatment. (4) Treating cows with low P4 during pre- and postdeviation periods exacerbated the incidence of double ovulations in cows that appeared to be predisposed to double ovulate based on random double ovulations during the pre-synchrony period.

\section{Low P4 Increased Chances of Pregnancy 23 d Post-Al}

The main objective of the present study was to determine the effects of inducing high or low serum concentrations of $\mathrm{P} 4$ during different stages of the ovulatory follicle growth on fertility of lactating dairy cows. Our hypothesis was that reduced serum concentrations of P4 during the dominance period of the ovulatory follicle would decrease P/AI and increase pregnancy loss during gestation. Results indicated that cows with low circulating $\mathrm{P} 4$ during both pre-dominance and dominance phases of ovulatory follicle development actually had greater P/AI on d 23 post-AI. Treatments did not affect the percentage of cows with short luteal phases in cows diagnosed not pregnant at $\mathrm{d} 23$, which could confound P/AI and pregnancy loss outcomes. Only $3 \%$ of all nonpregnant cows in the current study underwent luteolysis before $16 \mathrm{~d}$ post-AI. In a previous study, cows with low P4 during a synchronized ovulatory follicular wave had greater incidence of short luteal phase (before d 10 of the subsequent cycle) compared with cows with high P4 (25 vs. 0\%; Cerri et al., 2011a). Our study 
suggests that CL lifespan was not influenced in cows treated with low $\mathrm{P} 4$ during dominance of ovulatory follicle development. Short luteal phase-induced estrus in mid-cycle appears to me more of an issue related to incomplete luteolysis before AI (Peters and Pursley, 2003).
Several studies during the last decade investigated the effects of serum concentrations of P4 during the growth of the ovulatory follicle on fertility of cattle (Cunha et al., 2008; Denicol et al., 2012; Bisinotto et al., 2015b). The majority of past studies showed a positive relationship between circulating concentrations of
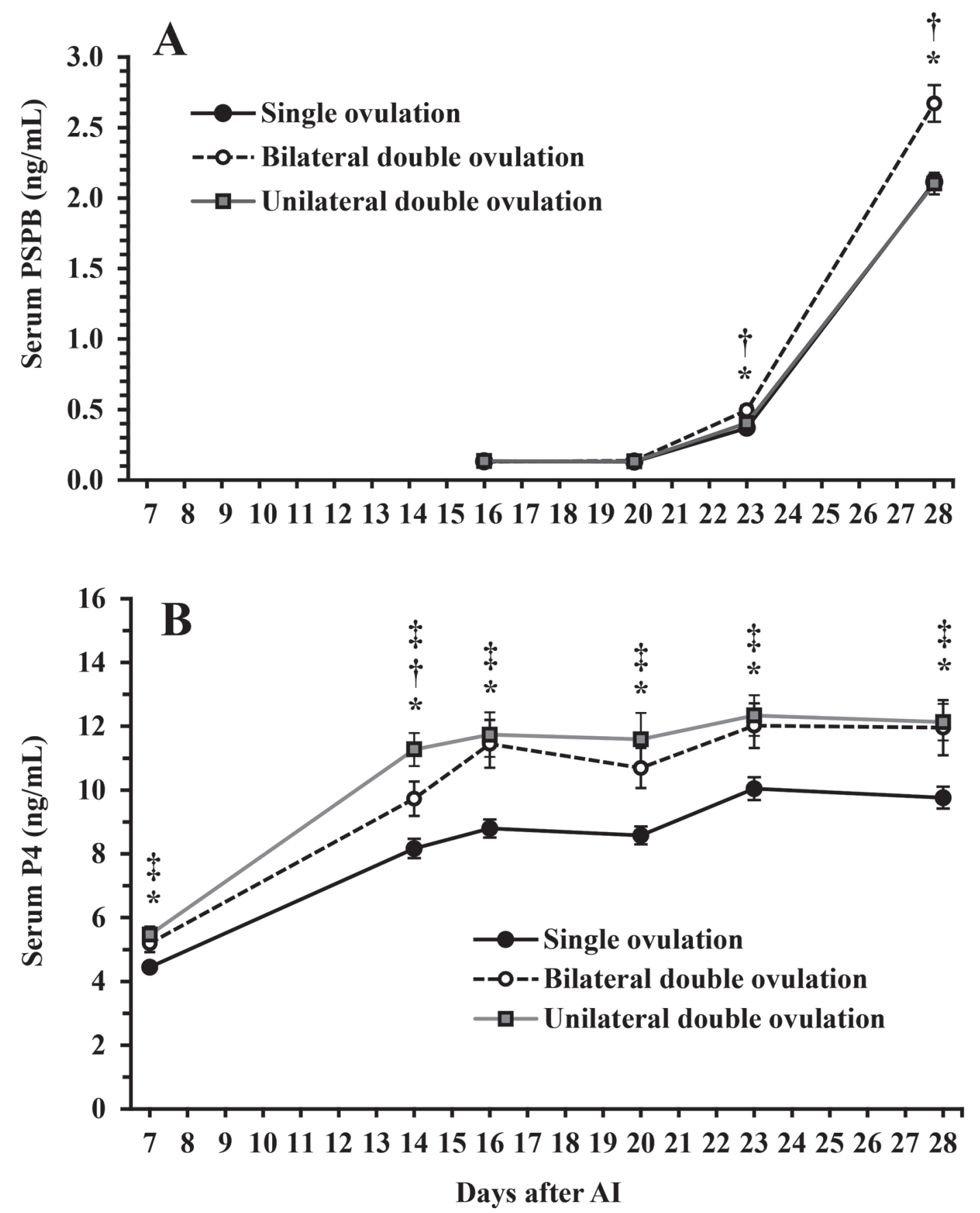

Figure 8. Mean \pm SEM serum concentrations of pregnancy-specific protein B (PSPB; A) and progesterone (P4; B) for cows $(n=319)$ pregnant at d 28 after AI with single ovulation and unilateral and bilateral double ovulation. Pairwise differences $(P<0.05)$ within a day are represented as follows: *single ovulation vs. bilateral double ovulation; †unilateral double ovulation vs. bilateral double ovulation; †single ovulation vs. unilateral double ovulation. 
Table 2. Effect of treatments on pregnancy per AI (P/AI) at d 23 post-AI, pregnancy losses during gestation, gestation length, calving, twinning, stillborn, and rates of each sex in cows treated with high or low progesterone $(\mathrm{P} 4)$ during either the pre-dominance (first $4 \mathrm{~d}$ following LH surge) or dominance ( $\mathrm{d} 5$ to 7 of the wave, from approximate time of deviation until luteolysis) period of ovulatory follicle development ( $\mathrm{H} / \mathrm{H}$ $=$ high $\mathrm{P} 4$ during pre-dominance and dominance; $\mathrm{H} / \mathrm{L}=$ high $\mathrm{P} 4$ during pre-dominance and low $\mathrm{P} 4$ during dominance; $\mathrm{L} / \mathrm{H}=$ low $\mathrm{P} 4$ during pre-dominance and high $\mathrm{P} 4$ during dominance; $\mathrm{L} / \mathrm{L}=$ low $\mathrm{P} 4$ during pre-dominance and dominance)

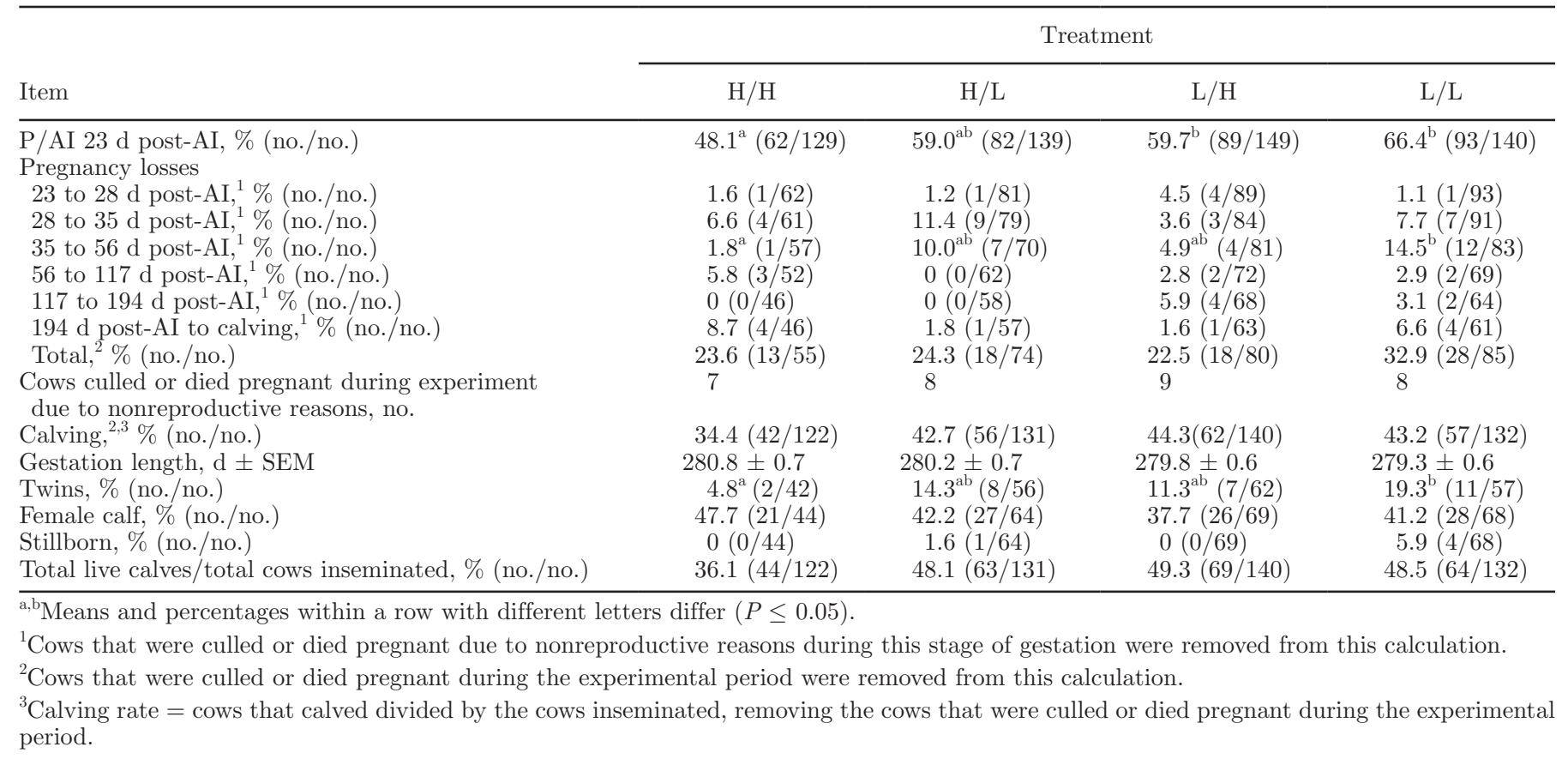

P4 during ovulatory follicle development and fertility of lactating dairy cows (Cunha et al., 2008; Denicol et al., 2012; Bisinotto et al., 2015b). A recent study compared $\mathrm{P} / \mathrm{AI}$ of cows with ovulations of first follicular wave follicles that developed under low P4 compared with cows that ovulated a second wave follicle that developed under greater P4 (Bisinotto et al., 2010). Cows with ovulatory follicles from second wave had greater P/AI compared with cows with ovulatory follicles from first wave (Bisinotto et al., 2010). Previous work that used a synchronization of ovulation program determined that cows without a CL at beginning of the program had lower $\mathrm{P} / \mathrm{AI}$ compared with cows with a CL, in diestrus (Bisinotto et al., 2013, 2015a). Furthermore, cows without a CL at the initiation of a synchronization of ovulation program that were supplemented with P4 (2 CIDR) had greater P/AI compared with cows without $\mathrm{CL}$ and similar P/AI compared with cows with CL (Bisinotto et al., 2013, 2015a). A recent meta-analysis of 25 controlled studies that used synchronization of ovulation protocols also identified a benefit of supplement P4 during the growth of the ovulatory follicle on P/AI (Bisinotto et al., 2015b).

Controlling time from emergence of a new follicular wave until ovulation was an important factor in this study. Previous data indicated that ovulatory follicles that developed under low circulating P4 for a long duration of dominance (persistent follicle) had lower fertility compared with cows with greater P4 and short duration of dominance (Mihm et al., 1994; Ahmad et al., 1995). The reduction of fertility in oocytes from persistent follicles have been attributed to $\mathrm{LH}$ overstimulation causing germinal vesicle breakdown (Revah and Butler, 1996).

\section{Low P4 Increased Chances of Double Ovulation}

The increase in fertility $23 \mathrm{~d}$ post-AI in the low $\mathrm{P} 4$ treated cows may be related to the increased double ovulation rate in $\mathrm{H} / \mathrm{L}, \mathrm{L} / \mathrm{H}$, and $\mathrm{L} / \mathrm{L}$ groups, resulting in greater numbers of oocytes having a chance for fertilization. However, it is not known if the increase in $\mathrm{P} /$ $\mathrm{AI} d 23$ post-AI in low $\mathrm{P} 4$ cows was caused by a greater fertilization rate or a greater embryonic survival between fertilization and d 23 post-AI or both. A previous report did not find differences in fertilization rate between cows with single or multiple ovulations at d 6 to 8 postmating ( $~ 80 \%$; Echternkamp, 1992). In addition, no differences were observed in percentage of embryos classified as normal or abnormal and oocytes classified as unfertilized d 6 to 8 postmating (Echternkamp, 1992 ) in this regard. Past reports also found greater P/ AI in cows with double ovulation compared with cows with singe ovulation (Echternkamp et al., 2007). 


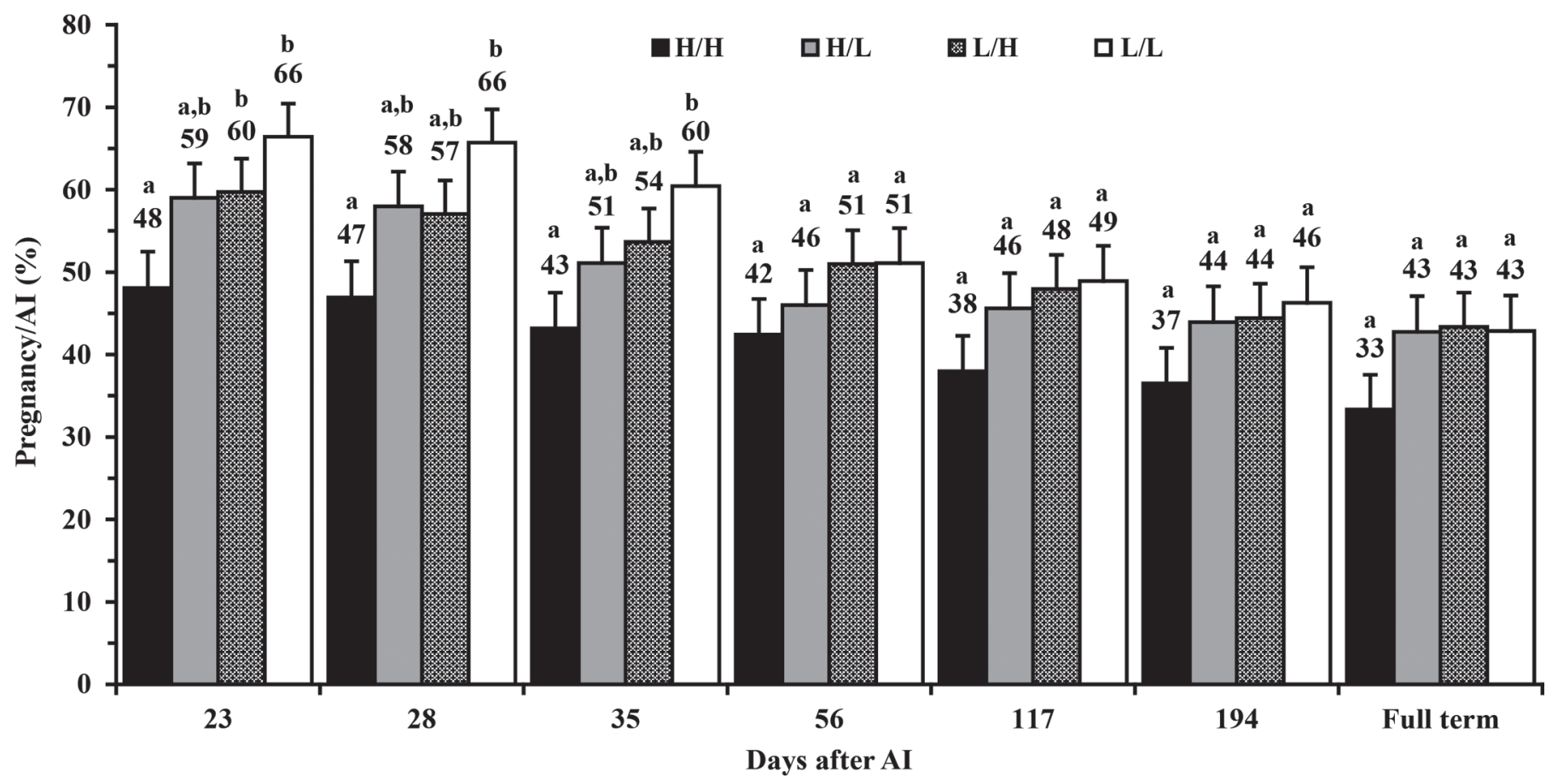

Figure 9. Effect of treatment on pregnancy per AI in different days after AI. Data are shown as mean \pm SEM. Different letters (a,b) within a day after AI represent differences of $\mathrm{LSM}(P<0.05) . \mathrm{H} / \mathrm{H}=$ high $\mathrm{P} 4$ during pre-dominance and dominance; $\mathrm{H} / \mathrm{L}=\mathrm{high} \mathrm{P} 4$ during pre-dominance and low $\mathrm{P} 4$ during dominance; $\mathrm{L} / \mathrm{H}=$ low $\mathrm{P} 4$ during pre-dominance and high $\mathrm{P} 4$ during dominance; $\mathrm{L} / \mathrm{L}=$ low $\mathrm{P} 4$ during predominance and dominance.

Cows with double ovulations had greater $\mathrm{P} / \mathrm{AI}$ compared with cows with single ovulations when treatments were combined. Previous research reported strong evidence of the effect of low $\mathrm{P} 4$ on increased incidence of double ovulation in cattle. Recent studies that manipulated low versus high circulating $\mathrm{P} 4$ with a controlled follicular wave similar to the present experiment showed that cows with low $\mathrm{P} 4$ during entire follicle development had a greater percentage of double ovulations compared with cows with high P4 (Cerri et al., 2011a,b). Heifers and cows with a follicular wave in the absence of a CL, thus very low circulating P4, had increased co-dominant follicles and double ovulation (Hayashi et al., 2008). This study suggested a role for the enhancement of LH pulses due to low circulating P4 on increased incidence of co-dominant follicles (Hayashi et al., 2008). In agreement, Lopez et al. (2005b) showed that cows with double ovulation had low circulating P4 and greater circulating LH and FSH before deviation compared with cows with single ovulations. High circulating P4 had an opposite effect on cows with a history of double ovulations and may be an efficient way to reduce double ovulation incidence in cows with a history of double ovulation. Although our results are in agreement with earlier studies regarding the effect of low circulating $\mathrm{P} 4$ on double ovulation, the percentage of cows with double ovulation was greater than previously reported $[18.6 \%$ (Cerri et al., 2011b), $20.6 \%$ (Cunha et al., 2008), 25.0\% (Cerri et al., 2011a), and $26.8 \%$ (López-Gatius et al., 2002)]. Fricke et al. (2016) did not detect an increase in double ovulation rate under a similar low $\mathrm{P} 4$ treatment during dominant follicle growth and deviation in Irish dairy cows. This lack of effect of treatments on double ovulation rate in the current experiment might be related to the lower milk production in the Irish cows, differences in genetic predisposition for double ovulations, or both. However, greater selection for fertility traits in Irish cows compared with the United States may be a reason for the differences in the 2 studies. It is not clear, however, if double ovulation is a trait affected by genetic merit calculations for fertility in Irish cows. Lopez et al. (2005a) reported a $45.3 \%$ incidence of double ovulation for cows with milk production between 45 and $<50 \mathrm{~kg} / \mathrm{d}$ and $51.6 \%$ for cows with milk production $\geq 50 \mathrm{~kg} / \mathrm{d}$. High milk production was associated with the increased metabolic clearance rate of steroid hormones due to greater feed intake and greater blood flow through the liver (Rabiee et al., 2001a,b; Sangsritavong et al., 2002).

The high and similar incidence of double ovulations in cows in the $\mathrm{H} / \mathrm{L}$ and $\mathrm{L} / \mathrm{H}$ treatments were not anticipated. It was expected that cows treated with $\mathrm{L} / \mathrm{H}$ may 


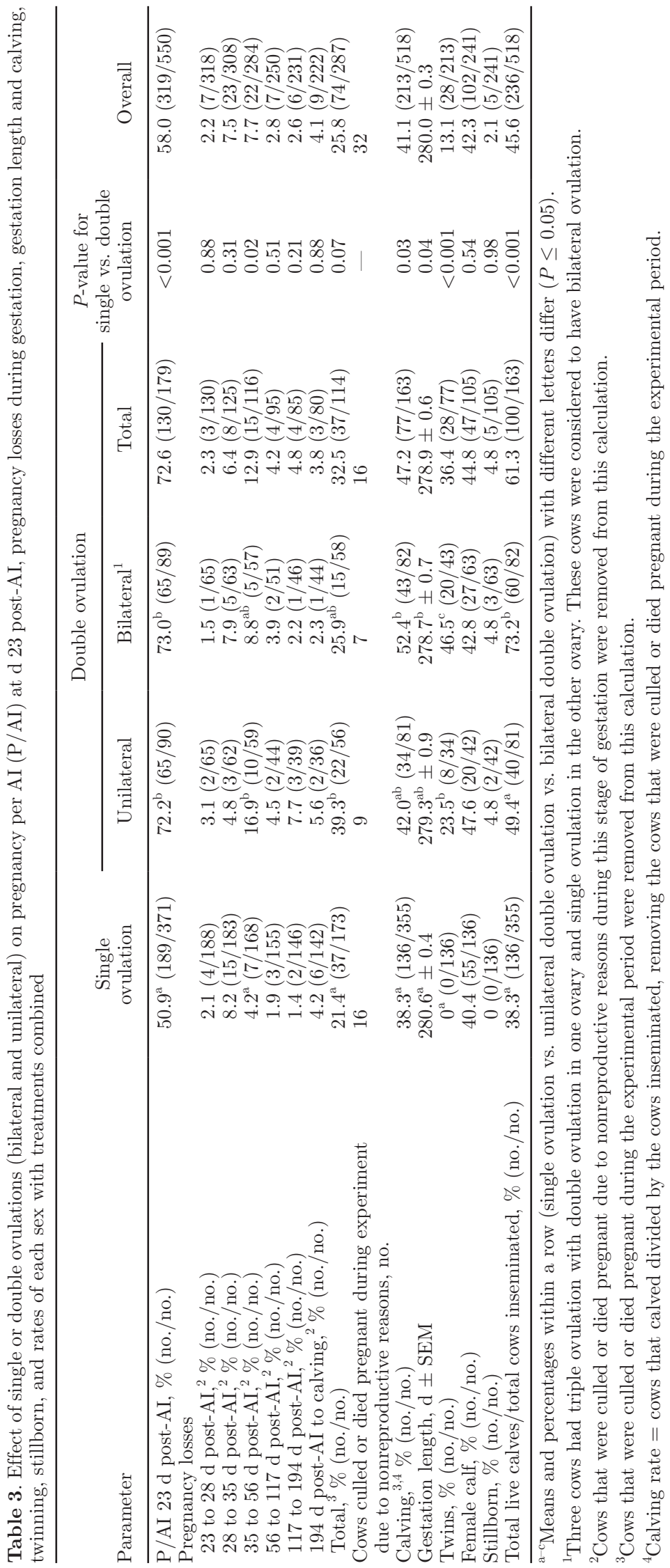




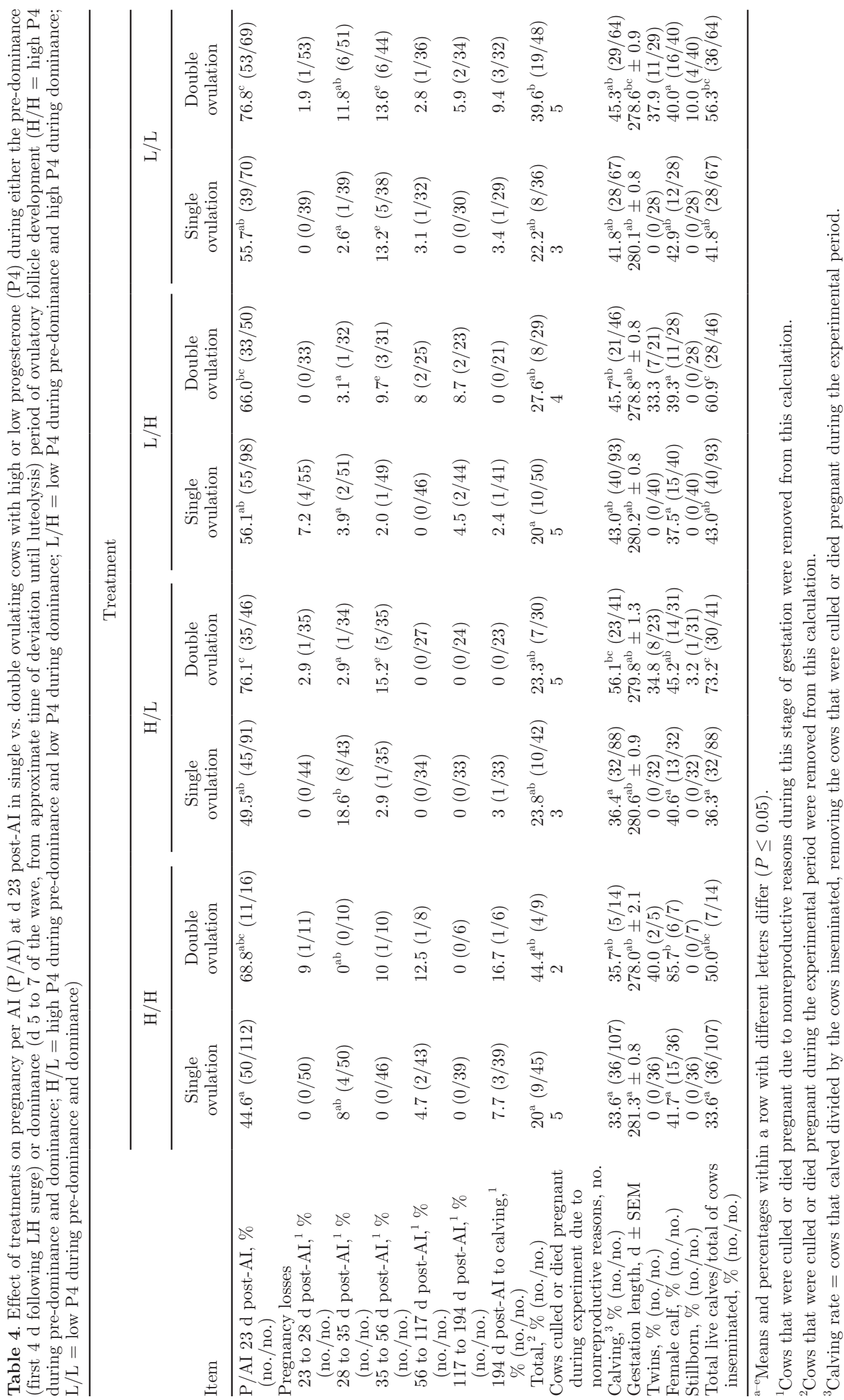


Table 5. Effect of low vs. high serum concentrations of progesterone (P4) during different phases of the ovulatory follicle development on pregnancy per AI (P/AI) at d 23 post-AI, pregnancy losses during gestation, gestation length, calving, twinning, stillborn, and rates of each sex in cows treated with high or low P4 during either the pre-dominance (first $4 \mathrm{~d}$ following LH surge) or dominance (d 5 to 7 of the wave, from approximate time of deviation until luteolysis) period of ovulatory follicle development $(\mathrm{H} / \mathrm{H}=$ high $\mathrm{P} 4$ during pre-dominance and dominance; $\mathrm{H} / \mathrm{L}=$ high $\mathrm{P} 4$ during pre-dominance and low $\mathrm{P} 4$ during dominance; $\mathrm{L} / \mathrm{H}=$ low $\mathrm{P} 4$ during pre-dominance and high $\mathrm{P} 4$ during dominance; $\mathrm{L} / \mathrm{L}$ $=$ low $\mathrm{P} 4$ during pre-dominance and dominance)

Treatments combined based on different concentrations of P4 during different phases of the ovulatory follicle development

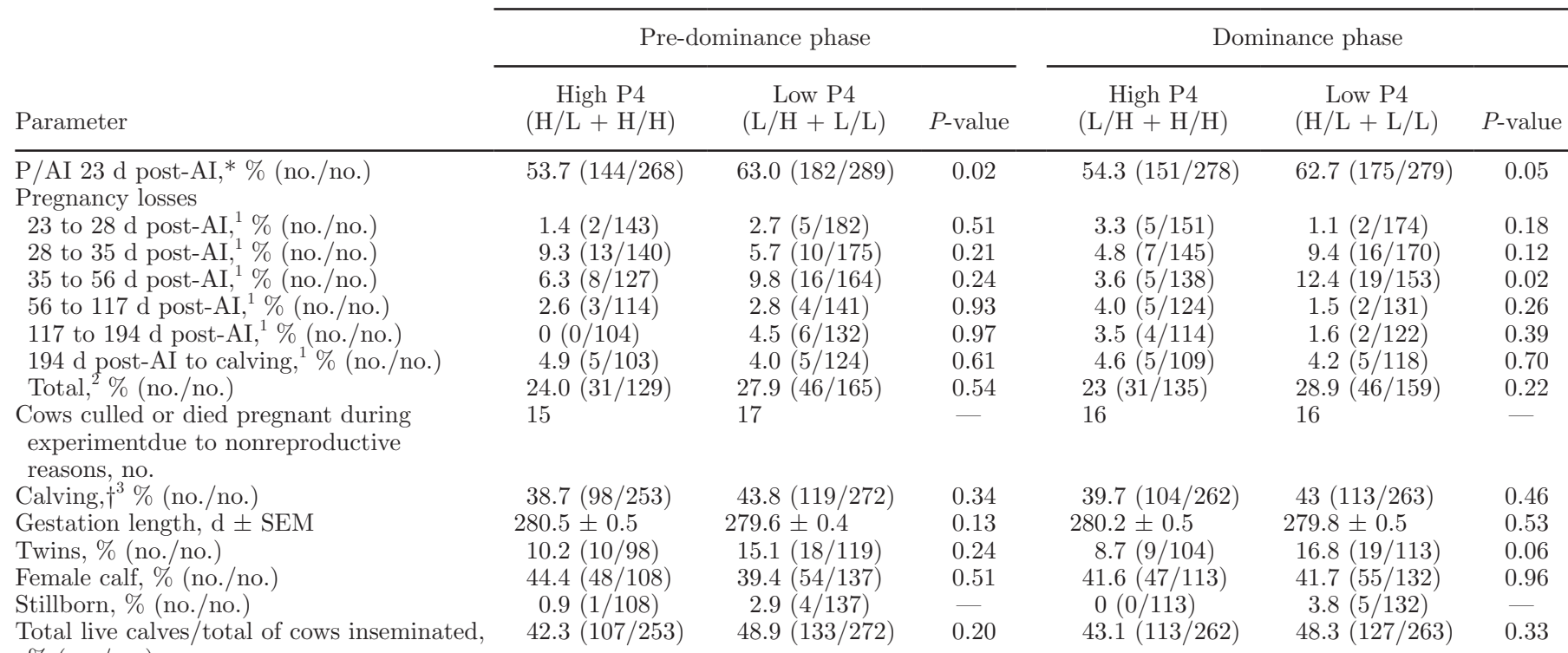

$\%$ (no./no.)

${ }^{1}$ Cows that were culled or died pregnant due to nonreproductive reasons during this stage of gestation were removed from this calculation.

${ }^{2}$ Cows that were culled or died pregnant during the experimental period were removed from this calculation.

${ }^{3}$ Calving rate $=$ cows that calved divided by the cows inseminated, removing the cows that were culled or died pregnant during the experimental period.

*Interaction between parity and treatment during the pre-dominance phase was observed for $\mathrm{P} / \mathrm{AI} 23 \mathrm{~d}$ post-AI $(P=0.15)$. Multiparous cows in $\mathrm{L} / \mathrm{H}$ and $\mathrm{L} / \mathrm{L}$ treatments combined during the pre-dominance phase of follicle development had greater $(P<0.01) \mathrm{P} / \mathrm{AI} 23 \mathrm{~d}$ post-AI compared with multiparous cows in $\mathrm{H} / \mathrm{H}$ and $\mathrm{H} / \mathrm{L}$ treatments combined during pre-dominance (65.4 vs. $51.7 \%$ ).

$\dagger$ Interaction between service and treatment during the pre-dominance phase was observed for calving rate $(P=0.09)$. First AI cows in $\mathrm{L} / \mathrm{H}$ and $\mathrm{L} / \mathrm{L}$ treatments combined during pre-dominance period had greater $(P=0.03)$ calving rate compared with first service cows in $\mathrm{H} / \mathrm{H}$ and $\mathrm{H} / \mathrm{L}$ treatments combined during pre-dominance phase (48.3 vs. $36.2 \%)$.

have greater double ovulations compared with cows treated with $\mathrm{H} / \mathrm{L}$ due to deviation occurring around $\mathrm{d}$ 4. We speculate that deviation of a single follicle may occur during a longer period than we anticipated. Thus, the second largest follicle in some cows in the H/L may have not become atretic before the $\mathrm{d} 4$ change to low $\mathrm{P} 4$. The increase in LH pulses may have kept this follicle functional, driving it to co-ovulate with a larger follicle. Conversely, the deviation event may have been delayed long enough in some cows in the $\mathrm{L} / \mathrm{H}$ group to cause some of the second largest follicles to become atretic compared with the $\mathrm{L} / \mathrm{L}$ treatment.

It was previously suggested that low circulating P4 would increase LH pulses and delay the decrease of circulating FSH to basal before deviation causing an increase on frequency of double ovulation in cattle (Wiltbank et al., 2014). A key event for follicle deviation is the acquisition of $\mathrm{LH}$ receptors in the granulosa cells (Xu et al., 1995; Beg et al., 2001; Sartori et al., 2001). Day of acquisition of LH receptors by granulosa cells (Xu et al., 1995; Bao et al., 1997; Beg et al., 2001) varied in previous studies. The estimate of time to deviation in the current study was based on data from Sartori et al. (2001). A difference of time to deviation between cows might be the reason for similar percentage of cows with double ovulation in treatment $\mathrm{L} / \mathrm{H}$ and $\mathrm{H} / \mathrm{L}$. Previous studies determined that the deviation event may occur in less than $8 \mathrm{~h}$ (Ginther et al., 1999; Kulick et al., 1999).

\section{Low P4 Increased Chances of Early Embryonic/Fetal Loss}

A greater percentage of cows with low $\mathrm{P} 4$ during dominance period of ovulatory follicle development had pregnancy loss between d 35 and 56 of gestation. 
Greater pregnancy losses during this period was observed in double and single ovulation cows with low P4 during dominance. Cows with unilateral double ovulation had greater pregnancy loss during this stage of gestation. Although cows with low $\mathrm{P} 4$ during the dominance period had greater P/AI d 23 post-AI, the percentage of cows calving was similar compared with cows with high $\mathrm{P} 4$ during the dominance phase. In addition to high $\mathrm{P} / \mathrm{AI}$ at $\mathrm{d} 23$ post-AI, cows with double ovulation had greater pregnancy losses between d 35 and 56 post-AI compared with single ovulation cows, primarily due to losses in cows with unilateral double ovulations. Echternkamp (1992) found a greater incidence of dead or degenerated fetus on d 52 of gestation for cows with triple ovulations or more and suggested that embryo death occurred at approximately d 35 of gestation based on fetal development. López-Gatius et al. (2002) also identified cows with twins with a greater risk of pregnancy loss (3.1 times greater) compared with singletons between $\mathrm{d} 38$ and 90 of gestation. In a later study, López-Gatius et al. (2010) found $28 \%$ of pregnancy losses in twin pregnancies between approximately d 30 and 60 post-AI. In a study with a large number of beef heifers and cows selected for multiple ovulations, twins had greater percentage of pregnancy losses than singletons (Echternkamp et al., 2007). In beef heifers selected for multiple ovulations, unilateral twin pregnancies had 2- to 3-fold greater pregnancy losses between d 75 to 135 of gestation compared with bilateral twin pregnancies.

One of the causes of pregnancy loss for unilateral twinning suggested was crowding of 2 embryos or fetuses within one horn (Echternkamp, 1992; Echternkamp et al., 2007). Expulsion or resorption of a single embryo was reported in cattle with twins (Kastelic et al., 1991; Giordano et al., 2012), in mares (Ginther, 1984), and in swine (Dziuk, 1985). Incidence of placental anastomosis in twin pregnancies in cattle is $>90 \%$ based on the frequency of freemartin in twin births (Zhang et al., 1994). Vascular anastomosis appears to preclude the expulsion or absorption of the dead fetus, which may lead to the death of the other viable fetus. Unfortunately, in the current study, twin data were not collected during pregnancy to determine if a reduction of embryo number occurred during this period. If both oocytes of cows with unilateral double ovulation were at the same location at time of fertilization and one was fertilized there was a high probability that the other would also be fertilized. In this case, cows in the present experiment with unilateral double ovulation may have had a greater percentage of one embryo loss compared with cows with bilateral double ovulations.

Unilateral twin pregnancies had a greater risk of losing one embryo compared with bilateral twin pregnancies
(López-Gatius et al., 2010). However, it was not determined if losses occurred before placental anastomosis. It has been reported that cows with losses between $\mathrm{d} 31$ and 60 of gestation had lower circulating PSPB already on d 24 of gestation (Ribeiro et al., 2014). Our results indicated that pregnant cows with unilateral double ovulations had lower circulating concentration of PSPB on d 23 and 28 of gestation compared with cows pregnant with bilateral double ovulation and similar compared with pregnant cows with single ovulation. This result could be due to the presence of just one viable embryo or due to 2 embryos in the same horn with impaired placentation. The PSPB and other pregnancyassociated glycoproteins or pregnancy-specific proteins are produced by binucleate cells. During placentation, the binucleate cells are critical for 2 main functions: formation of the fetal-maternal syncytium critical for implantation and subsequent placentome formation; and production and secretion of other proteins and steroid hormones such as somatomammotropin hormone 1 (CSH1 or placental lactogen) and P4. Taken together, these results suggest that the placentation process in unilateral twins may be compromised.

The increase in serum concentrations of PSPB from basal d 20 to 23 post-AI was used as a marker for pregnancy in the present study. Circulating concentrations of PSPB have been used as a marker for pregnancy diagnosis on and after $28 \mathrm{~d}$ post-AI with high specificity and sensibility. To our knowledge, this is the first time that circulating concentrations of PSPB have been used as a maker of pregnancy on d 23 post-AI. Data from our laboratory (Arnold et al., 2012) and others (Ribeiro et al., 2014) have shown that PSPB concentrations increase in pregnant cows around d 22 after AI. An early and accurate diagnostic method for pregnancy would be of extremely important for dairy producers to rebreed nonpregnant cows earlier.

Concentrations of PSPB on d 23 and 28 were related to pregnancy losses between 28 and $35 \mathrm{~d}$ post-AI, but not later periods ( 35 to 56 and $>56$ to calving). This was not confounded by parity even though primiparous cows had greater PSPB compared with multiparous. The lack of a relationship in later pregnancy losses is likely due to potential greater losses of twins after d 35 post-AI because cows with twins have greater PSPB. It was clear that cows with double ovulations had greater PSPB than single ovulators.

In conclusion, circulating concentrations of $\mathrm{P} 4$ during ovulatory follicle wave development affected diameter of the ovulatory follicle and rate of double ovulations. Cows with a history of double ovulation during pretreatment had a greater probability of double ovulation regardless of treatment; however, induction of high P4 during ovulatory follicular development appears to re- 
duce the risks of double ovulation in these cows. The hormonal environment of the growing pre-ovulatory follicle appears to be a regulator of subsequent pregnancy loss. Low P4 during follicular development created greater losses from 35 to $56 \mathrm{~d}$ post-AI. Most of these losses were likely due to unilateral twins.

\section{ACKNOWLEDGMENTS}

Thanks to the Michigan Alliance for Animal Agriculture (Michigan State University, East Lansing) for partial funding of this project. A special thanks to Ken and Kerry Nobis and all employees of Nobis Dairy Farm, St. Johns, Michigan, for allowing the use of their cows. Thanks to Zoetis (Florham Park, NJ) for providing Lutalyse, Factrel, and CIDR that were used in this study. The authors also thank BioTracking Inc. (Moscow, ID) for the donation of BioPRYN assays that was used in this experiment. J. P. N. Martins, G. F. Rossi, and A. P. Martini were supported by a $\mathrm{CNPq}$ fellowship - Science without Borders program (Brazil). D. Wang and N. Mu were supported by Shuozhou Vocational and Technical College (Shuozhou City, Shanxi, China). And last but not least, thanks to undergraduates Megan Ahearne and Brandi Stone (Michigan State University) for their assistance on the project.

\section{REFERENCES}

Acosta, T. J., N. Yoshizawa, M. Ohtani, and A. Miyamoto. 2002. Local changes in blood flow within the early and midcycle corpus luteum after prostaglandin $\mathrm{F}$ (2 alpha) injection in the cow. Biol. Reprod. 66:651-658.

Ahmad, N., F. N. Schrick, R. L. Butcher, and E. K. Inskeep. 1995. Effect of persistent follicles on early embryonic losses in beef cows. Biol. Reprod. 52:1129-1135.

Arnold, H., J. P. N. Martins, L. Z. Oliveira, R. K. Policelli, K. M. Stomack, G. Sasser, and J. R. Pursley. 2012. Effectiveness of pregnancy-specific protein $\mathrm{b}$ in pregnancy diagnosis of dairy cows and heifers. J. Dairy Sci. 95(Suppl. 1):128.

Bakke, L. J., M. P. D. Dow, C. A. Cassar, M. W. Peters, J. R. Pursley, and G. W. Smith. 2002. Effect of the preovulatory gonadotropin surge on matrix metalloproteinase-14, matrix metalloproteinase-2 and tissue inhibitor of metalloproteinase-2 expression within bovine periovulatory follicular and luteal tissue. Biol. Reprod. 66:1627-1634

Bakke, L. J., Q. Li, C. A. Cassar, M. P. D. Dow, J. R. Pursley, and G. W. Smith. 2004. Gonadotropin surge induced differential upregulation of collagenase-1 (MMP-1) and collagenase-3 (MMP-13) mRNA and protein in bovine preovulatory follicles. Biol. Reprod. 71:605-612.

Bao, B., H. A. Garverick, G. W. Smith, M. F. Smith, B. E. Salfen, and R. S. Youngquist. 1997. Changes in messenger ribonucleic acid encoding luteinizing hormone receptor, cytochrome P450-side chain cleavage, and aromatase are associated with recruitment and selection of bovine ovarian follicles. Biol. Reprod. 56:1158-1168.

Beg, M. A., D. R. Bergfelt, K. Kot, M. C. Wiltbank, and O. J. Ginther. 2001. Follicular-fluid factors and granulosa-cell gene expression associated with follicle deviation in cattle. Biol. Reprod. 64:432-441.

Bello, N. M., and J. R. Pursley. 2007. Strategies to maximize ovulation to first GnRH of Ovsynch in lactating dairy cows. J. Dairy Sci. 90(Suppl. 1):326-328. (Abstr.)
Bello, N. M., J. P. Steibel, and J. R. Pursley. 2006. Optimizing ovulation to first GnRH improved outcomes to each hormonal injection of ovsynch in lactating dairy cows. J. Dairy Sci. 89:3413-3424.

Bisinotto, R. S., L. O. Castro, M. B. Pansani, C. D. Narciso, N. Martinez, L. D. P. Sinedino, T. L. C. Pinto, N. S. Van de Burgwal, H. M. Bosman, R. S. Surjus, W. W. Thatcher, and J. E. P. Santos. 2015a. P4 supplementation to lactating dairy cows without a corpus luteum at initiation of the Ovsynch protocol. J. Dairy Sci. 98:2515-2528.

Bisinotto, R. S., R. C. Chebel, and J. E. P. Santos. 2010. Follicular wave of the ovulatory follicle and not cyclic status influences fertility of dairy cows. J. Dairy Sci. 93:3578-3587.

Bisinotto, R. S., I. J. Lean, W. W. Thatcher, and J. E. P. Santos. 2015b. Meta-analysis of $\mathrm{P} 4$ supplementation during timed artificial insemination programs in dairy cows. J. Dairy Sci. 98:2472-2487.

Bisinotto, R. S., E. S. Ribeiro, F. S. Lima, N. Martinez, L. F. Greco, L. F. S. P. Barbosa, P. P. Bueno, L. F. S. Scagion, W. W. Thatcher, and J. E. P. Santos. 2013. Targeted P4 supplementation improves fertility in lactating dairy cows without a corpus luteum at the initiation of the timed artificial insemination protocol. J. Dairy Sci. 96:2214-2225.

Cerri, R. L. A., R. C. Chebel, F. Rivera, C. D. Narciso, R. A. Oliveira, M. Amstalden, G. M. Baez-Sandoval, L. J. Oliveira, W. W. Thatcher, and J. E. P. Santos. 2011a. Concentration of P4 during the development of the ovulatory follicle: II. Ovarian and uterine responses. J. Dairy Sci. 94:3352-3365.

Cerri, R. L. A., R. C. Chebel, F. Rivera, C. D. Narciso, R. A. Oliveira, W. W. Thatcher, and J. E. P. Santos. 2011b. Concentration of P4 during the development of the ovulatory follicle: I. Ovarian and embryonic responses. J. Dairy Sci. 94:3342-3351.

Cunha, A. P., J. N. Guenther, M. J. Maroney, J. O. Giordano, A. Nascimento, S. Bas, H. Ayres, and M. C. Wiltbank. 2008. Effects of high vs. low circulating P4 concentrations during Ovsynch on double ovulation rate and pregnancies per AI in high producing dairy cows. J. Dairy Sci. 91(Suppl 1):246.

Denicol, A. C., G. Lopes, L. G. D. Mendonça, F. A. Rivera, F. Guagnini, R. V. Perez, J. R. Lima, R. G. S. Bruno, J. E. P. Santos, and R. C. Chebel. 2012. Low P4 concentration during the development of the first follicular wave reduces pregnancy per insemination of lactating dairy cows. J. Dairy Sci. 95:1794-1806.

Dow, M. P. D., L. J. Bakke, C. A. Cassar, M. W. Peters, J. R. Pursley, and G. W. Smith. 2002a. Gonadotropin surge-induced upregulation of the plasminogen activators (tissue plasminogen activator and urokinase plasminogen activator) and the urokinase plasminogen activator receptor within bovine periovulatory follicular and luteal tissue. Biol. Reprod. 66:1413-1421.

Dow, M. P. D., L. J. Bakke, C. A. Cassar, M. W. Peters, J. R. Pursley, and G. W. Smith. 2002b. Gonadotropin surge-induced upregulation of messenger RNA for plasminogen activator inhibitors 1 and 2 within bovine periovulatory follicular and luteal tissue. Reproduction 123:711-719.

Dziuk, P. 1985. Effect of migration, distribution and spacing of pig embryos on pregnancy and fetal survival. J. Reprod. Fertil. Suppl. 33:57-63.

Echternkamp, S. E. 1992. Fetal development in cattle with multiple ovulations. J. Anim. Sci. 70:2309-2321.

Echternkamp, S. E., R. A. Cushman, M. F. Allan, R. M. Thallman, and K. E. Gregory. 2007. Effects of ovulation rate and fetal number on fertility in twin-producing cattle. J. Anim. Sci. 85:3228-3238.

Fonseca, F. A., J. H. Britt, B. T. McDaniel, J. C. Wilk, and A. H. Rakes. 1983. Reproductive traits of Holsteins and Jerseys. Effects of age, milk yield, and clinical abnormalities on involution of cervix and uterus, ovulation, estrous cycles, detection of estrus, conception rate, and days open. J. Dairy Sci. 66:1128-1147.

Fricke, P. M., P. D. Carvalho, M. C. Lucy, F. Curran, M. M. Herlihy, S. M. Waters, J. A. Larkin, M. A. Crowe, and S. T. Butler. 2016. Effect of manipulating progesterone before timed- artificial insemination on reproductive and endocrine parameters in seasonal calving, pasture-based Holstein Friesian cows. J. Dairy Sci. 99:6780-6792. 
Ginther, O. J. 1984. Postfixation embryo reduction in unilateral and bilateral twins in mares. Theriogenology 22:213-223.

Ginther, O. J., D. R. Bergfelt, L. J. Kulick, and K. Kot. 1999. Selection of the dominant follicle in cattle: Establishment of follicle deviation in less than 8 hours through depression of FSH concentrations. Theriogenology 52:1079-1093.

Ginther, O. J., L. A. Silva, R. R. Araújo, and M. A. Beg. 2007. Temporal associations among pulses of 13,14-dihydro-15-keto-PGF2alpha, luteal blood flow, and luteolysis in cattle. Biol. Reprod. $76: 506-513$.

Giordano, J. O., J. N. Guenther, G. Lopes, and P. M. Fricke. 2012. Changes in serum pregnancy-associated glycoprotein, pregnancyspecific protein $\mathrm{B}$, and circulating $\mathrm{P} 4$ concentrations before and after induction of pregnancy loss in lactating dairy cows. J. Dairy Sci. 95:683-697.

Hayashi, K.-G., M. Matsui, T. Shimizu, N. Sudo, A. Sato, K. Shirasuna, M. Tetsuka, K. Kida, D. Schams, and A. Miyamoto. 2008. The absence of corpus luteum formation alters the endocrine profile and affects follicular development during the first follicular wave in cattle. Reproduction 136:787-797.

Jimenez-Krassel, F., J. P. N. Martins, S. Raghavendra, M. Kron, and J. R. Pursley. 2012. Enhancing endogenous P4 during growth of the ovulatory follicle is positively associated with fertility in dairy cows treated with Presynch-11/Ovsynch, Double Ovsynch, and G6G/Ovsynch. J. Dairy Sci. 95(Suppl. 2):74.

Kastelic, J. P., D. L. Northey, and O. J. Ginther. 1991. Spontaneous embryonic death on Days 20 to 40 in heifers. Theriogenology 35:351-363.

Kulick, L. J., K. Kot, M. C. Wiltbank, and O. J. Ginther. 1999. Follicular and hormonal dynamics during the first follicular wave in heifers. Theriogenology 52:913-921.

Lopez, H., D. Z. Caraviello, L. D. Satter, P. M. Fricke, and M. C. Wiltbank. 2005a. Relationship between level of milk production and multiple ovulations in lactating dairy cows. J. Dairy Sci. 88:2783-2793.

Lopez, H., R. Sartori, and M. C. Wiltbank. 2005b. Reproductive hormones and follicular growth during development of one or multiple dominant follicles in cattle. Biol. Reprod. 72:788-795.

Lopez, H., L. D. Satter, and M. C. Wiltbank. 2004. Relationship between level of milk production and estrous behavior of lactating dairy cows. Anim. Reprod. Sci. 81:209-223.

López-Gatius, F., I. Garcia-Ispierto, and R. H. F. Hunter. 2010. Factors affecting spontaneous reduction of corpora lutea and twin embryos during the late embryonic/early fetal period in multipleovulating dairy cows. Theriogenology 73:293-299.

López-Gatius, F., P. Santolaria, J. Yániz, J. Rutllant, and M. LópezBéjar. 2002. Factors affecting pregnancy loss from gestation Day 38 to 90 in lactating dairy cows from a single herd. Theriogenology 57:1251-1261.

Martins, J. P. N., T. Cunha, C. Piterinni, and J. R. Pursley. 2017. The effect of pre-synchronization with PGF2 $\alpha$ and GnRH simultaneously, $7 \mathrm{~d}$ prior to Ovsynch, compared to Presynch-10/Ovsynch on luteal function and first service pregnancies per AI. J. Dairy Sci. 100:5107-5116.

Martins, J. P. N., R. K. Policelli, L. M. Neuder, W. Raphael, and J. R. Pursley. 2011a. Effects of cloprostenol sodium at final prostaglandin F $2 \alpha$ of Ovsynch on complete luteolysis and pregnancy per artificial insemination in lactating dairy cows. J. Dairy Sci. 94:2815-2824

Martins, J. P. N., R. K. Policelli, and J. R. Pursley. 2011b. Luteolytic effects of cloprostenol sodium in lactating dairy cows treated with G6G/Ovsynch. J. Dairy Sci. 94:2806-2814.

Martins, J. P. N., and J. R. Pursley. 2016. Fertility programs for lactating dairy cows, their physiological basis, and the factors that are critical for their success. Anim. Reprod. 13:283-289.

Mihm, M., A. Baguisi, M. P. Boland, and J. F. Roche. 1994. Association between the duration of dominance of the ovulatory follicle and pregnancy rate in beef heifers. J. Reprod. Fertil. 102:123-130.

Moreira, F., C. Orlandi, C. A. Risco, R. Mattos, F. Lopes, and W. W. Thatcher. 2001. Effects of presynchronization and bovine so- matotropin on pregnancy rates to a timed artificial insemination protocol in lactating dairy cows. J. Dairy Sci. 84:1646-1659.

NRC. 2001. Nutrient Requirements of Dairy Cattle. 7th rev. ed. Natl. Acad. Sci., Washington, DC.

Peters, M. W., and J. R. Pursley. 2002. Fertility of lactating dairy cows treated with Ovsynch after presynchronization injections of $\mathrm{PGF}_{2 \mathrm{a}}$ and GnRH. J. Dairy Sci. 85:2403-2406.

Peters, M. W., and J. R. Pursley. 2003. Timing of final GnRH injection of Ovsynch affects ovulatory follicle size, subsequent progesterone concentrations, and fertility. Theriogenology 60:1197-1204.

Pursley, J. R., M. R. Kosorok, and M. C. Wiltbank. 1997a. Reproductive management of lactating dairy cows using synchronization of ovulation. J. Dairy Sci. 80:301-306.

Pursley, J. R., and J. P. N. Martins. 2011. Impact of circulating concentrations of $\mathrm{P} 4$ and antral age of the ovulatory follicle on fertility of high-producing lactating dairy cows. Reprod. Fertil. Dev. 24:267-271.

Pursley, J. R., M. O. Mee, and M. C. Wiltbank. 1995. Synchronization of ovulation in dairy cattle using $\mathrm{GnRH}$ and $\mathrm{PGF}_{2 \mathrm{a}}$. Theriogenology 44:915-923.

Pursley, J. R., R. W. Silcox, and M. C. Wiltbank. 1998. The effect of time of AI on pregnancy rates, calving rates, and pregnancy loss after synchronization of ovulation in lactating dairy cows. J. Dairy Sci. 81:2139-2144.

Pursley, J. R., M. C. Wiltbank, J. S. Stevenson, J. S. Ottobre, H. A Garverick, and L. L. Anderson. 1997b. Pregnancy rates of cows and heifers inseminated at a synchronized ovulation or synchronized estrus. J. Dairy Sci. 80:295-300.

Rabiee, A. R., K. L. Macmillan, and F. Schwarzenberger. 2001a. The effect of level of feed intake on $\mathrm{P} 4$ clearance rate by measuring faecal P4 metabolites in grazing dairy cows. Anim. Reprod. Sci. $67: 205-214$.

Rabiee, A. R., K. L. Macmillan, and F. Schwarzenberger. 2001b. P4 metabolism in ovariectomised non-lactating Holstein-Friesian cows treated with P4 with two levels of feed intake. Anim. Reprod. Sci. $66: 35-46$.

Revah, I., and W. R. Butler. 1996. Prolonged dominance of follicles and reduced viability of bovine oocytes. J. Reprod. Fertil. 106:3947.

Ribeiro, E. S., R. G. S. Bruno, A. M. Farias, J. A. Hernández-Rivera, G. C. Gomes, R. Surjus, L. F. V. Becker, A. Birt, T. L. Ott, J. R. Branen, R. G. Sasser, D. H. Keisler, W. W. Thatcher, T. R. Bilby, and J. E. P. Santos. 2014. Low doses of bovine somatotropin enhance conceptus development and fertility in lactating dairy cows. Biol. Reprod. 90:10. https://doi.org/10.1095/biolreprod.113 .114694 .

Roche, J. F., and J. J. Ireland. 1981. The differential effect of P4 on concentrations of luteinizing hormone and follicle-stimulating hormone in heifers. Endocrinology 108:568-572.

Sangsritavong, S., D. K. Combs, R. Sartori, L. E. Armentano, and M. C. Wiltbank. 2002. High feed intake increases liver blood flow and metabolism of P4 and estradiol-17beta in dairy cattle. J. Dairy Sci. 85:2831-2842.

Sartori, R., P. M. Fricke, J. C. Ferreira, O. J. Ginther, and M. C. Wiltbank. 2001. Follicular deviation and acquisition of ovulatory capacity in bovine follicles. Biol. Reprod. 65:1403-1409.

Sartori, R., J. M. Haughian, R. D. Shaver, G. J. M. Rosa, and M. C. Wiltbank. 2004. Comparison of ovarian function and circulating steroids in estrous cycles of Holstein heifers and lactating cows. J. Dairy Sci. 87:905-920.

Sasser, R. G., C. A. Ruder, K. A. Ivani, J. E. Butler, and W. C. Hamilton. 1986. Detection of pregnancy in radioimmunoassay of a novel pregnancy-specific protein in serum of cows and a profile of serum concentrations during gestation. Biol. Reprod. 35:936-940.

Souza, A. H., A. P. Cunha, E. P. Silva, A. Gümen, H. Ayres, J. N. Guenther, and M. C. Wiltbank. 2009. Comparison of gonadorelin products in lactating dairy cows: Efficacy based on induction of ovulation of an accessory follicle and circulating luteinizing hormone profiles. Theriogenology 72:271-279. 
Stevenson, J. S., J. R. Pursley, H. A. Garverick, P. M. Fricke, D. J. Kesler, J. S. Ottobre, and M. C. Wiltbank. 2006. Treatment of cycling and non-cycling dairy cows with progesterone during Ovsynch. J. Dairy Sci. 89:2567-2578.

Stevenson, J. S., D. E. Tenhouse, R. L. Krisher, G. C. Lamb, J. E. Larson, C. R. Dahlen, J. R. Pursley, N. M. Bello, P. M. Fricke, M. C. Wiltbank, D. J. Brusveen, M. Burkhart, R. S. Youngquist, and H. A. Garverick. 2008. Detection of anovulation by heatmount detectors and transrectal ultrasonography before treatment with progesterone in a timed insemination protocol. J. Dairy Sci. 91:2901-2915.

Wiltbank, M., H. Lopez, R. Sartori, S. Sangsritavong, and A. Gümen. 2006. Changes in reproductive physiology of lactating dairy cows due to elevated steroid metabolism. Theriogenology 65:17-29.

Wiltbank, M. C., and J. R. Pursley. 2014. The cow as an induced ovulator: Timed AI after synchronization of ovulation. Theriogenology $81: 170-185$.

Wiltbank, M. C., A. H. Souza, P. D. Carvalho, A. P. Cunha, J. O. Giordano, P. M. Fricke, G. M. Baez, and M. G. Diskin. 2014.
Physiological and practical effects of $\mathrm{P} 4$ on reproduction in dairy cattle. Animal 8:70-81.

Xu, Z., H. A. Garverick, G. W. Smith, M. F. Smith, S. A. Hamilton, and R. S. Youngquist. 1995. Expression of follicle-stimulating hormone and luteinizing hormone receptor messenger ribonucleic acids in bovine follicles during the first follicular wave. Biol. Reprod. 53:951-957.

Yousuf, M. R., J. P. N. Martins, N. Ahmad, K. Nobis, and J. R. Pursley. 2016. Pre-synchronization of lactating dairy cows with PGF2 $\alpha$ and $\mathrm{GnRH}$ simultaneously, 7 days prior to Ovsynch have similar outcomes compared to G6G. Theriogenology 86:1607-1614.

Zhang, T., L. C. Buoen, B. E. Seguin, G. R. Ruth, and A. F. Webber. 1994. Diagnosis of freemartinism in cattle: The need for clinic and cytogenic evaluation. J. Am. Vet. Med. Assoc. 204:1672-1675.

Zuluaga, J. F., and G. L. Williams. 2008. High-pressure steam sterilization of previously used CIDR inserts enhances the magnitude of the acute increase in circulating $\mathrm{P} 4$ after insertion in cows. Anim. Reprod. Sci. 107:30-35. 